\title{
Social Identity and Biological Identity
}

\author{
Viviana Bernath, Ph.D. in Molecular Biology \\ Director, MyGen S.A. \\ Director, GENDA S.A.
}

Translated by Jane Ramirez

In the last twenty years the term DNA has become synonymous with identity. A few decades ago we used to say "it's in the blood" to indicate that a trait, a preference, or a career choice was innate, inherited, hardwired into one's very being. Today, we are more likely to say "it's in the genes" or "it's in the DNA." This reveals, on the one hand, the massive dissemination of knowledge about the discovery of DNA and the development of DNA technologies. On the other hand, popular use of the term is evidence that, at least in our collective unconscious, our biological side-what we are born with, what we cannot choose or alter-is still a matter of great significance in our society.

As with any scientific advance of revolutionary proportions, the transformations brought about by the discovery of DNA are not limited to mere human behavior. On the contrary, this new knowledge enables us to revise our perspective on more profound questions, such as identity, on both a theoretical and a personal plane.

"Who am I?" "Where did I come from?" These queries are common to all people throughout human history. The majority of us believe that we have an answer to these questions, at least on the biological level: we belong to a family, we know our place on our branch of the family tree and therefore we know, or at least we think we know, where we came from and who we are.

It is, however, in the exceptions-the stories of those who know nothing of their origins and who now have a real possibility (through DNA analysis) of discovering them-that a more profound investigation can be made. Are we what we were born with, what we carry in our genes? Are we what we do and what we make of ourselves? Or are we, perhaps, a tangled web of primitive biological matter intertwined with our life experiences, both good and bad?

In the following pages we will listen to the voices of those who were the subjects of legal adoption, illegal adoption (suppression or substitution of iden- 
tity), or baby theft (appropriation $\left.{ }^{1}\right)$. We will also hear from specialists in various disciplines. This will enable us to shed some light on the topic of identity and how it is formed. We will learn some of the reasons why people who do not know about their origins feel compelled to investigate them. We will learn what it is that the seekers seek.

\title{
Substitution, Adoption, Appropriation
}

\section{In Search of Lost Origins}

The Case: A Christmas card confirms what Mariela has always intuitively suspected: she is not the biological daughter of her parents. From that moment forward, nothing can quench her thirst to discover her origins.

\section{The Characters}

\author{
Mariela (the daughter) \\ The father \\ The mother \\ The godfather \\ Hilda (a friend of the family)
}

Mariela arrives right on time for our meeting in a restaurant. With her long wavy hair, she does not seem like the same shy girl who, too timid to talk about her life, had hesitated for a long time before accepting our invitation. On the contrary, she proudly displays the openness typical of her thirty-two years. In fact, after we have introduced ourselves and accepted our beverages from the waiter, she eagerly responds to my first question...

Viviana Bernath: Could you tell me about that moment in your life when you first realized that you were adopted?

Mariela: One day my teacher at the nursery school called my mom to congratulate her because I, at only four years of age, had told her that I was adopted. "Good for you, ma'am, for telling your little girl the truth," she told her. That same day, when I got home from school, my mom scolded me, she hit me, she yelled at me, "Where did you get those ideas?" The truth is, I had always felt, deep inside of me, that I didn't belong in that family.

My parents adopted me when the doctors discovered that it was because of my father that they weren't able to have a baby. It was in '76 and they had already

1. "Appropriation" of identity refers to a phenomenon of the period of the military dictatorship in Argentina from 1976-83, when children of the "disappeared ones"-hereinafter the desaparecidos-were systematically placed with politically approved families. Trans. 
been married for six years, during which time my mother had been subjected to one treatment after another but never managed to get pregnant.

When I was four years old my mom got sick. I don't really know what she had, but from that time on I was living with a woman who was in and out of hospitals, popping pills, with phobias about everything, practically insane. I was terrified of her.

I don't know if it was because of her illness, but I could see that my mom didn't take care of me the way my friends' moms took care of them. She treated me like I was in the way. When I found out I was adopted, I also learned that she never wanted children. It was my dad who looked for a baby to adopt and found me. But I felt like I didn't belong to my family. When I was older, I started to look for clues to help me find out who I was. I had set myself the task of finding a picture of my mom when she was pregnant. When I realized that it didn't make sense to keep looking because I wasn't going to find anything, I confronted her. "Where are those photos?" Her answer was that back then people didn't usually take pictures of pregnant women. But all of my friends had at least one ... I also used to listen closely to women's conversations... When one woman was talking about the lower-back pain that she had when she was pregnant, the weight gain, the nausea ... I noticed my mom's silence. I looked at her with her green eyes and her light-colored hair and then I looked at myself with my black hair and brown eyes. I couldn't bear the silence any longer and I asked her, "Who do I look like?" Dubiously, she answered, "You? You have your Grandpa Pedro's eyes." She was trying to be convincing, but I didn't believe her.

Obviously, she never talked about giving birth. It was impossible to get even one word out of her. When I would ask her something, she would avoid the question. I had never been allowed to see my birth certificate, either. I would ask for it, but they never gave it to me. My friends and their mothers encouraged me to look for it. Whenever my parents went out, I tried repeatedly to find it, looking everywhere, in drawers, in cupboards, in the boxes that they had under the bed. It never showed up. I was going to a psychologist who also urged me to continue with the search. She was sure that they were hiding it from me. I asked my grandmother, my aunt, and my cousins what they remembered about my birth. And they all kept quiet. My father, however, would feel like he was being attacked and he would go on the defensive and ask me whether they had ever treated me badly and tell me that I was an ungrateful daughter, that they always gave me everything but I always wanted more. He even threatened me, saying that if I wasn't satisfied, I could leave.

V. B.: And when did you find out for sure?

M.: My suspicions were confirmed right when I least expected it. One day, just before Christmas, my mom gave me a letter addressed to me that had come in the mail. I pulled a card out of the envelope. It had a Nativity scene on one side and on the other it said, "Just as Jesus and Mary received you and your parents 
adopted you." When I read that, I literally almost died. I could not stop crying; my reaction was a panic attack. Even though the letter told me what I had always wanted to know, what really hurt was the way that I found out. If my parents had sat down in front of me and told me the truth, I think I might even have thanked them for their sincerity. But to find out a few days before Christmas, that time of the year when emotions are all stirred up...

When my dad came home, I was still furious, I yelled and screamed at him; I was out of control. Mom just sat there watching us. My dad started to blame her for having told me their most sacred secret. She had broken the pact. They had a big argument. In the end, she was the one who stopped and said, "Yes, you were adopted."

V. B.: What about the letter? Who had sent it?

M.: I always thought that it was my godfather. He and my father worked together and around that time they had a fight and dissolved the partnership that they had. He must have done it for revenge. The next morning, when we had all calmed down, I asked them again for an explanation. But the only thing they told me was that now that I knew the truth, I had to decide whether to stay and not ask any more questions about my past and accept my father's rules or to simply go away...

I felt lost. I didn't have anywhere to go. I didn't have a job. I hadn't even finished high school. My dad didn't want me to get an education. He thought that the more ignorant I was, the less possibility there was that I would find out who I was. If I wanted to go to school, I went; nobody made me go. I finished grade school because my teachers felt sorry for me because I was adopted. It sounds ridiculous, but that was the way things worked. I didn't go out with friends much. My parents didn't really want me to have friends, either. I wasn't allowed to go out to dance. Going out was dangerous. Talking to people was dangerous. The real danger was that if I went out, I might meet someone out there who would awaken me and let me find out who I was. My dad wanted to keep me to himself. He knew that if I went out into the world, he ran the risk of losing me.

Once I had learned that I was adopted, the conditions that they imposed on me in order to stay with them were terrible, like I was in the army. But they were my parents... The one thing that they allowed me to do was to go drink mate with a neighbor. She was the one who suggested that if I thought that my godfather had sent that card, I should stop wasting time and go talk with him. I took her advice. When I went to see him, even though he denied having sent the card, he did not hesitate to tell me that not only had he always known the truth, but also he had been the one to go fetch me when I was a newborn and take me to my parents. He explained that the woman who bore me was very poor and didn't want to keep me. The shacks in the neighborhood where she lived were unsafe and she was unable to provide for me or take care of me. That's when I learned that I was born in Temperley, in a house near the corner of Pasco and Salta. While I was 
talking with him, I couldn't stop crying. That day I went home, but I didn't mention my visit to anyone. I tried to find out some of my history, but always behind my parents' backs. A few days later I went to see him again and after I begged him to tell me something else that would enable me to find her, he admitted that my Aunt Rosa had also been involved in finding me. He suggested that I go see her. But she did not add much to what I already knew. In fact, she repeated the same story. So I was going between one and the other of those who knew I was adopted and getting nowhere, and in the end it seemed that everyone knew about it but me, and they were all reading from the same script. No one added any new information.

Then, one evening in 2001, I was watching the news and I saw an interview with a couple of people who belonged to a group that tried to help people find out about their biological origins. That's how I learned about Raiz Natal.

V. B.: And did you go?

M.: Yes. I was a lost soul at the time. I felt like things couldn't get any worse. Mariana welcomed me and invited me to join a group. I joined up then and there. They encouraged me to keep questioning my family. They were sure that somebody would eventually let something slip.

I kept at them so much that one time I managed to get one of my aunts to admit that she had heard how a friend of my parents', Hilda, had made all the contacts so that they could get me. When I found Hilda, she didn't give me any new information. It was the same story of a poor woman who lived at Pasco and Salta, who was around twenty years old, who wanted to give up her baby girl. She thought that my birth mother already had a son at the time, and that after she gave me up she had another one. However, she said that if I wanted more information I should go back and ask my mother. After all, it was with her that the deal had been made.

But at that time I was still living in my parents' house, under their rules, and they were not aware that I had met up with the group and that I was busy trying to find my birth family. Confronting them would be complicated for me; I didn't have a job, I didn't have a boyfriend...

For more than two years I was stuck. Then in 2005 they found out that my mom had a tumor in her kidney and they had to operate. During those days while she was hospitalized, my neighbor suggested that I question her. So I did. One afternoon I showed up at the hospital and announced to her that I was going to stay and take care of her that night. My mother didn't accept that easily; she insisted that I had to go home. But I finally got what I wanted. It was already late when I confessed that I had stayed with her because I needed for her to tell me everything she knew about where I came from. I told her that I met from time to time with the group and that I was determined to find my biological family, and that if I had to, I would go to the news media, to the radio, to magazines, to whatever I could use to find out more. I didn't give her any options; she had to choose between co- 
operating with me or losing me. She was sentimental that day; she cried and told me that she had always loved me and that I was the one who had rejected her. Different points of view. Anyway, though, everything changed after that day. After all those years, I awoke from my lethargy and began to enjoy life. My mom had barely recovered when the two of us went to Hilda's house. But she repeated the same story... At about that same time I met a guy and I moved in with him. We had a son, Juan. If my relationship with my mother improved substantially after her operation, she really opened up with me after Juan's birth. Again and again she repeated that she had always loved me, that when they made the deal for me, she wasn't sure that she wanted a child. She had just begun to get accustomed to the idea of adoption when I showed up. It was like they suddenly announced to her that she had had a baby. She had become a mother overnight.

By then I was giving up on the idea of finding my birth family when Patricia, the president of Raíz Natal, suggested that I do an interview with a journalist from Gente magazine. I accepted. They asked me for two photos of me, one from when I was very little and one recent one. Both pictures were published in the magazine. Two weeks later, Patricia called me to say that a young woman who had read my story and had seen the pictures was interested in getting in touch with me. She said that I looked like her brothers and that, in addition, right at the time when I was born someone had stolen a daughter from her mother. Not knowing the truth was eating me up inside. I called her and we agreed to meet at the group's headquarters. They were five siblings; the two older ones were men and then came three sisters. Two of the sisters came to see me. As soon as I saw them, I was disappointed; I didn't think I looked like them at all. When I calmed down, I could see that maybe I looked like the older one. Actually, the two of them were very different from each other. One looked more like her father and the other looked more like her mother. Then when they showed me photos of the two brothers, I thought that maybe they could be my family after all. Their story was that in between the two older boys, their mother had had a baby girl who was born in the Quilmes hospital. At the time, she was twenty-three years old and lived on Pasco Street, two blocks from Salta. The mother had gone to the hospital alone; her husband was at work. No one was at her side when her baby was born. Later, they had brought the baby to her to nurse. Suddenly, she noticed that her baby girl's hands seemed to be cold. She called a nurse and they took her away to check her. But hours went by and they never brought her back, telling her that the baby was under observation. When her husband arrived and asked to see his daughter, they pointed out a crib on the far side of the room. All he could see was a little dark head. They didn't let him go any closer. They spent the whole night that way, waiting... When morning came they were told that their baby girl had died. The mother couldn't understand it. According to what they had told her, her daughter had a good birth weight, her heart was fine, she was healthy. They asked to see 
her body and were told no. The baby was never given to them; they were told that there would be an autopsy.

Although she had five other children, every time she remembered that baby girl, her mother could not stop crying, and she would tell the story over and over, in minute detail.

As I listened to them, I became almost convinced that I was that little girl who had "died" in the Quilmes hospital. Moreover, I immediately remembered that my godfather lived in that area and that he had made the contact to get me... I just needed to confirm it with a DNA test...

V. B.: Was it a hard decision to make?

M.: Yes... The thing is, it's tough, because you fantasize all your life about an idyllic situation, because you don't feel right or happy where you are, and later everything becomes difficult, one way or another... I could have left the story like that, closed the book, but I chose to find out the truth. I had the test done without meeting my mom first-I mean, the one who could be my mom-because she had a heart condition, and an emotional experience like that... Her children used her toothbrush to get a simple of her DNA.

$V$. B.: Did waiting for the results make you anxious?

M.: Yes, very. And it was also disappointing... The analysis turned out negative.

V. B.: Are you going to keep looking?

M.: Yes, of course. I feel like I have to at least try any way I can to find out where I came from, to learn who I am ...

\section{The Family Tree}

The Case: Cristina is an adult when she learns that the people who raised her are not her biological parents and she sets out in search of her birth mother, a course from which there is no turning back.

The Characters

Cristina Malvestiti (the daughter)

The mother

The father

Irene (the cousin)

Miguel (the ex-husband)

The dance teacher

Osvaldo (Cristina's new partner)

Omar (Cristina's possible brother)

Alberto (another possible brother) 
Although Cristina Malvestiti's story has some points in common with Mariela's, it has some unexpected twists. Once again I begin the conversation by asking about the moment when she first suspected that she had been adopted.

Viviana Bernath: When did it first occur to you that you were adopted?

Cristina Malvestiti: My mom had light skin and very unusual eyes, beautiful, in a color that was between yellow and caramel, like a cat's eyes. When I was little she used to tell me-like she was trying to convince me-"Your eyes look just like mine, but darker." In reality they're not at all alike; mine are small and brown. But like any child, biological or not, I had my parents as models and began to pick up their gestures and ideas; perceiving the differences is not easy. I did not begin to suspect that I was adopted until adolescence. I had a happy childhood. I was Mommy and Daddy's little girl, and they treated me like a princess. We were a well-to-do middle-class family. My father was a musician, a member of an important tango orchestra. Whenever he was on tour, my mom, like a good wife and homemaker in service to a great artist, would take charge of everything, including me. When I reached puberty at the age of twelve, the chubby little girl turned into a grown-up woman. At that moment my mom began to view me as a rival for my dad's attention. There started to be friction between us. Like many other adolescents, I wondered if I was adopted. For the first time, I questioned my identity. Most of my friends eventually realized that their doubts were unfounded, but I was still floating in a sea of questions. When we fought, my mom would attack me, saying that she wanted to disfigure me, scratch me, tear off that cheap doll-face that I had. There was something about me that she could not stand. Her jealousy over my father's love was really excessive.

V. B.: Did you tell her about your doubts at this time?

C. M: Oh no, I didn't have the nerve to confront them. I preferred to ask my cousin Irene what she knew about me. But there was a pact of silence among the women of the family, her mother and mine, that kept her from telling me anything.

My parents were unable to have children. Before I came along, my mom used to get pregnant, but could never carry the baby to term. She always miscarried at seven or eight months. After eight years of anguish over the failed attempts, my mom had become resigned to never being a mother. But not my dad.

I was fifteen and I knew by heart the story that my mother had carefully concocted about the day of my birth. Every year, after I had blown out the candles but before cutting the cake, she called for silence and repeated to everyone present the story... her story: that I was born at 9:00 at night on Good Friday. My mother had been hospitalized for two days. My dad had a show to do and my grandma, who was there with them, had insisted that he go to work. She never forgot to emphasize that at the moment when she gave birth to me, my father had abandoned her, that his music was more important to him than his wife-or his daughter? It was strong stuff; it would take courage to question it.

But as time went by, I noticed that my mom couldn't decide just where the 
clinic was where I was born. Sometimes it was in Flores; sometimes it was in $\mathrm{Pa}$ ternal. It migrated all over Buenos Aires.

When I outgrew my adolescence, I gave up the idea that maybe I had been adopted. I married very young and had two children. The idea recently reappeared, twenty-five years later, when I found a tangible clue.

My daughter was in her fourth year of high school when a teacher showed them how to put together a family tree and illustrate it with photographs. And then, going through some papers in a box, I found my birth certificate. . . There it was, a wrinkled, bug-stained piece of paper. It took a real effort to read enough to figure out what it was. My first impulse was to throw it away, but I stopped myself in time. I started to read: first my name, then my parents' names, and below that, my place of birth... That stopped me. The address was 121 Pasaje El Cardenal, Liniers. I read again the name of the street, the house number, the neighborhood. That was the address of the house where I lived until the age of five. Something didn't fit . . . My mom had always said that I was born in a clinic.

At that time, I was living with my husband and children on the second floor of a building and my parents were on the ground floor. Paper in hand, I ran down the stairs, entered my parents' home, showed my mother the document that I had found, and nervously asked her to explain. All that she could produce was a faint smile. A smile that hung there in silence until at last she spoke. "I don't understand why it shows that address. You were born in a clinic, here in the Capital. You can hardly expect me to remember the address after forty years. There you go again with your crazy ideas." Her reply was unacceptable. I have two children, and where they were born is not a minor detail. I could tell you the time of day, what the weather was like, the route that we took in the car on the way to the hospital, everything...

That same day I called my cousin Irene. I told her that I had found my birth certificate and I explained why I was confused. But if she knew anything, she wasn't ready to talk about it yet. Then I decided to request a new copy of my birth certificate, alleging that I had lost the other one. The new one showed the same address as the first. I got out my children's certificates for comparison. They were born in Santojani and the address that was written on their certificates was that of the hospital: 950 Pila. My home address did not appear anywhere on them. That day I talked with my son, the older of my children. I explained the situation and asked him for help. I went back to my cousin Irene's house, but this time my son went with me. I showed her the new birth certificate and pleaded with her to tell me the truth. Drops of sweat broke out on Irene's forehead; she couldn't bear to lie to me anymore. I was forty years old when she told me, "You were adopted." Over and over she said, "You're not going to love me anymore. I lied to you. You're going to hate me." The two of us started to cry together. Far from hating her, I felt that by telling the truth she had given part of my life back to me.

V. B.: Did you confront your parents at that time? 
C. M.: Not immediately. Even though I was an adult, I still needed to plan out ahead of time how I was going to confront them. One Sunday morning I invited them to breakfast. Only one of my children knew what was going to happen that day. I had gone to the trouble of making three photocopies of my lovely new birth certificate. I rolled up each one and tied it with a little white ribbon. They looked like three diplomas. I placed them on a tray next to the coffee cups and sat down to wait for them. Only my mom came. My husband Miguel, my children, my mother, and I were there. And then before I said a thing, my mom asked what those rolls of paper were. I took one, handed it to her, and suggested that she read it. She unrolled it and when she saw what it was, she fell silent. In the end, I was the one who read the document: "Name: Cristina Malvestiti; date of birth . . ." I stopped, looked up, and asked my mother, "Is this the truth?" My mother did not answer. I continued, "Place of birth: 121 Pasaje El Cardenal." I stopped again and repeated the question, "Is this the truth?" She was frightened; she got up and started shouting, asking what this insanity was, what I was driving at. I answered that I simply wanted to know whether what it said there on the paper was true. What my name was. Who I was. In concrete terms, my question was whether I was adopted. My mother looked to my husband for help. She could see that he knew the truth, even if she continued to deny it. Then, fenced in by my eyes and by those of Miguel and the children, she could do no other than to answer, "Let's put an end to all of this. You were adopted." Immediately she asked, in a threatening way, what I was going to do now that I knew. In self-defense, I replied that I was thankful that I was not her daughter, that I did not carry her genes. The truth is that my mom was not a very nice person. She could be a dictator, giving others little voice in the matter. Shortly after that, I confirmed my suspicion that my husband, from whom I soon separated, had known the truth about me for a long time. Not only he, but the entire neighborhood knew it as well. When I was little, the stigma of adoption placed everyone involved, both children and parents, in the category of victims. Just knowing about it inspired people to pity, so they preferred not to mention the subject. Miguel and I had known each other since we were young; we were part of the same bunch of neighborhood friends. I have never understood how he could keep it quiet for so long...

$V$. B.: And what happened when your mother confirmed your suspicions?

C. M.: That very day I asked her how they had gotten me. And she was the one who gave me the first clue in the search for my origins. She told me about some friends, a married couple named Morán. The man was the singer for the orchestra that my father played in. My mother told me that she and Mrs. Morán were sitting at a table one day, waiting for their husbands to finish a performance. Mrs. Morán brought up the subject of children and mentioned that she had miscarried several times, just like my mother. Then she said that she knew that they were trying to get a baby and that she knew of a girl who had recently had a baby girl that she wanted to give up. When the event was over and my mom mentioned 
to my dad the possibility of getting me, he didn't hesitate and she wasn't given a chance to think about it; in that instant, Fate determined that she was about to become a mother. The following day they went to fetch me, and just like that, she had a daughter.

Two days after the confrontation, my father, with whom I had not yet talked, came up to my house. He sat on the bed and started out by saying that on that morning when I had invited them to breakfast, he had an inkling that I was going to talk about my adoption, and that was why he had decided not to participate. He hadn't wanted to talk in public. Then, after asking me not to interrupt, he began to tell his story. After repeating the same story about the Moráns and confirming to me that he had gone personally to fetch me, he gave his approval to my search and offered to go with me to talk to them.

$V$. B.: Were they still in touch with each other?

C. M.: No, not at all, so it wasn't easy to find them, much less to persuade them to talk with me about it. But after a lot of comings and goings, I got them to tell me what they knew about me. It was Mrs. Morán who talked. Her two sons had been born in Fiorito Hospital, and she had made friends with the midwife who had attended her. The midwife had told her that she frequently attended teenagers who gave birth and then abandoned their babies. That day, when she and my mother were waiting for their husbands to finish their performance, the midwife had called her to say that she had a newborn girl whose mother wanted to give her up. The midwife wanted to know if she could help place the baby. That is what Mrs. Morán told my mother. My parents talked it over and decided to take in the baby. She put them in touch with the midwife. She was just the go-between and she assured me that she knew nothing more, not even whether a deal was or was not made or how things turned out.

Having heard the Moráns' story, I returned home. I couldn't confront my father, because he was in the middle of a serious health problem at the moment. He looked too feeble to me. I couldn't talk to my mom either, who died unexpectedly two years later. My mother took her secret to the grave. And with her death I broke off my search...

But soon after that, some friends of mine suggested that I take my case to the Office of the Ombudsman [Defensoría del Pueblo]. Through them I obtained information about the midwife who was involved in my case. Unfortunately, the woman was born in 1903, so obviously she had died by then, and it was not possible to find her and ask her for explanations. With that possibility eliminated, I went to the Fiorito Hospital. But they had no birth register there for '64, the year I was born.

At this point I took a hiatus; right after this I separated from my husband. I decided to cool things down for a while and work on fixing my personal problems. I suddenly found myself alone with my two children, and I needed to adapt to a new way of life. 
It was around this time that several remarkable incidents happened to me. I lived in Caseros, close to the business district, in a neighborhood where everyone knew everyone else. On more than one occasion I had gone into some business or store and been mistaken for someone else. Once it was a shoe-repair shop. The clerk asked me why I kept breaking so many pairs of shoes. I had been there the day before with some brown ones to repair and I had some black ones that day. When I answered that I had not been there the day before, he didn't believe me until he went and checked the tag on the brown shoes; the name of the woman who had left them was not mine.

On another day I had a legal errand to run in the Tres de Febrero district party and when they put me on the list they said, "Here you are again today, maiam!" I told them that I had never been to that office before. They didn't believe me either, until the clerk compared my DNI [National Identity Document] number with that of the woman whom they had previously waited on.

But what led me to seek out "that woman" was another episode. I am a dance teacher, and so is my daughter. A couple of months ago I went with her to the club where she teaches. While we were there a teacher from another group asked me how I was. Surprised, I said, "Excuse me, but I don't know you." He tried to help me remember him, but I couldn't. I had never seen him before. Then it occurred to me to ask him who he thought I was, and he responded that I was Omar's sister. Omar was a friend of his who lived in a zone where there were many people from Paraguay. He didn't remember the exact address of Omar's house, but he described the place to me. If I got off the bus at the 500 block of a certain street and walked straight to the middle of the block, I would find an alley. Omar lived in one of the houses that faced that alley. Besides, in that same block there was a storage facility of the Tres de Febrero municipality. He also told me that Omar's family was from Misiones and that he had something like ten siblings. I took careful note of all of his instructions. I was beginning to feel intrigued... Obviously, if so many people mistook me for a particular woman and this woman appeared to be one of Omar's sisters, there might be a connection to my birth family; they might be my brothers and sisters... But time went by and I never talked myself into going there... Finally I was at the club again and I bumped into the dance teacher who was Omar's friend. Not only did he ask me if I had gone to see Omar, but also he offered to go with me. He insisted that I ought to go; he assured me that I looked just like one of the sisters, and added that it was a good, hardworking, close-knit family. But I didn't want to go ...

However, that same day when I got home, I asked Osvaldo, my new partner, to go with me. It was a cold and rainy Saturday afternoon in July. We took the bus and got off in a very poor neighborhood. We found out where the municipal storage facility was and found the alley. There we saw a man and we asked about Omar's family. To my surprise, he was one of Omar's brothers. Without wasting an instant I told him about the many times that I had been mistaken for some 
other woman, who was apparently one of his sisters. I also explained that I had been adopted and was looking for my biological family.

The man gazed at me and then called his wife to ask her if she thought I looked like one of his sisters. The woman looked me over from head to toe and finally said that yes, I looked like Claudia. Then I told them my story in detail and explained why I had decided to bother them. They not only understood, but also offered to let me converse with the older sisters who knew more about the family history. I thanked them, but said that this was sufficient for that day. We exchanged phone numbers and agreed to talk again, and Osvaldo and I left.

It had not been even an hour. . . I was opening the door at home when I heard the telephone ring. I asked Osvaldo to hurry and answer it. It was Alberto, the man we had just been with a short time before. His sister wanted to talk with me. In fact, she wanted me to go back to her house right then. But it was late and I didn't want to go, or couldn't go. We agreed that I would go there again on the following day, at six oclock in the afternoon.

The whole family was there at their house, waiting for me. We arrived at the alley... There at the door Alberto and his wife were waiting. Inside was a multitude of people who wanted to meet me. People of all sizes, some bigger, some smaller, both young and not so young. Everyone was giving me furtive looks. I felt confused. Evidently there was something that no one had told me yet. We joined the circle of mate drinkers. My eyes darted about, trying to find a woman sitting there who looked like me. I didn't see her.

They asked me to tell my story. My voice was breaking as I struggled to tell them all the details of what I had been through and how I had found my way to them. When I paused, it was one of the sisters who told me that, yes, I looked like one of the two sisters who had been unable to come that afternoon. They called her Monona. There were seven siblings present: five women and two men. Their mother had died three years earlier. They had grown up knowing that their mother had given up her first child, a daughter. Over and over they had heard her crying with regret. She had ten children, but the mother had always mourned the one that she did not have.

After their marriage, the couple immigrated to Buenos Aires. When they first arrived, the wife was pregnant and when their daughter was born, they still did not have a stable job or a place to live. So they decided to give up the baby. They figured that they were young and that they would have many more children. And they did-but the woman had never been able to forget that little girl.

Then the husband of one of the sisters spoke up, suggesting that only a DNA test could tell us for sure what we wanted to know.

At first I was not at all sure; it wasn't an easy decision to make. Besides, even if I didn't like it-and to tell the truth, I didn't like it-I had a feeling that these people not only were telling the truth, but also were my family. And I didn't feel the happiness that I had expected to feel, in all likelihood because they were con- 
firming something that I had always feared: that my birth mother had given me up voluntarily. As a result, I spent more than a month thinking about whether or not I wanted to do the test. Finally, I decided to do it, because I had to learn the truth and close the book on my history. After all, even if the test came out positive, I had no obligation to them. Even though they were my biological family, I didn't have to see them ever again if I didn't want to. That possibility made me feel better, because even though they treated me very well, I don't know, I felt like a frog in the wrong pond...

V. B.: It wasn't anything like you had dreamed it would be ...

C. M.: Not at all. We fantasize so many things . . but even if reality was something very different, I felt that since I had come so far, I needed to take that one last step. Obviously, I couldn't take the test with my theoretical mother, but her children went. The truth is that waiting for the results was agonizing.

V. B.: But you finally found out...

C. M.: Yes, the results were positive. At first I really didn't know what to do. But now I'm adjusting; little by little, I'm getting to know them. Sometimes I feel more open, other times I don't. I think I need to give myself time. They are a lot of siblings, when they're all together, and we are different, with different histories. Although, of course, the most important thing is having learned the truth. As I said, now I am the one who gets to choose...

Mariela's and Cristina's histories are similar in many aspects. The first thing that grabs our attention is that both came to their adoptive families illegally, a practice that was, until recently, quite common among couples who were unable to have children biologically. The practice was socially approved-or, at least, it was not condemned. Using a variety of euphemisms to try to soften the illegality of the procedure, people would say that a couple had "received a baby", had "obtained" or "found" a child, or even that they had "adopted" one. All of this took place in deep secrecy within the adult world, for the good of the new arrival, so that the child would not learn about the circumstances. This would hypothetically cause him or her to "suffer" terribly for having been abandoned and make the child a target for mockery, bullying, and discrimination. This refusal to recognize the illegality of "obtaining" a child had reached - and still reaches-such an extreme that even the central figures of these histories, Cristina and Mariela, knowing the truth, continue to refer to themselves as "adopted."

An interview with Dr. Elsa Freijo ${ }^{2}$ provides us with an opportunity to clarify, from a legal point of view, the difference between adoption and obtaining a child illegally. "Adoption is an act administered by a judicial procedure," Freijo explains, "in which a judge determines that a subject ceases to be the child of

2. Dr. Elsa Freijo is an attorney with expertise in Children and Family. She teaches at the University of Buenos Aires and cooperates with the human rights groups Raíz Natal and Grandmothers of the Plaza de Mayo. 
its biological parents and becomes the child of other persons, who from that moment are the child's adoptive parents. It is the judge who renders the legal decision establishing that, for whatever cause, a minor has become an adopted child. We all know that, throughout history, there have been people who, evading the proper legal channels, obtain children to raise as their own. Generally these cases are referred to as 'illegal adoptions.' This phrase, however, refers to a situation that simply does not exist, since adoption can be called 'adoption' only within a legal framework. Any other procedure that turns a child into the son or daughter of a man and woman, without the intervention of the court, is not an adoption; it is a substitution of identity and is considered a crime. In the sphere of civil justice it is called 'substitution of identity' while in that of criminal justice it is known as 'falsification of public records', since the data shown on birth certificates, marriage records, etc., are false. Except in cases involving a crime against humanity, these acts are finalized after twelve years, for which cause they can, in general, be tried only in civil court."

Of course, as Roland Barthes says, "language is never innocent." Words always come with their own scope and significance: "obtain," "receive," even "adopt illegally" presuppose an action taken outside the law, perhaps worthy of condemnation from sources external to the family circle; they do not, however, imply-at least not explicitly-any harm done to the child who is the object of that action. In contrast, "substitution of identity" refers directly to a detrimental effect on the child who has been transformed into a son or daughter. To "substitute" means to put one thing in the place that belongs to another; to change, in fact to lie about, a person's identity. And surely, if there is a second element that links the histories of Mariela and Cristina, it is lies.

Both of them-one in early childhood and the other in adolescence-sense that they do not belong to the families that have raised them. Each perceives that her birth is surrounded by a peculiar silence or by contradictions that are never explained. As a result, each lives in a state of constant doubt and insecurity. By different routes (Mariela via an anonymous breach of confidence and Cristina via her own deductions) the two confirm what they had long suspected: they are not the biological daughters of their parents. Both, in the end, decide to undertake a search for the truth, that truth that will enable them to complete their identities-as Mariela puts it, to learn who they are. In a sense, they seek to recover their suppressed identities, the ones that were denied them when the truth was concealed.

By chance and a physical resemblance, Cristina finds a family that could be hers. The question that, not so long ago, would have lingered in the nebulous realm of possibilities now finds its definitive answer. Science intervenes. Transcending the coincidences and the histories that appear to jibe, a DNA test clears away all doubts and opens a door to the freedom that exists in any human relationship, with or without biological connections. 
In the same way, but with the opposite outcome, Mariela also obtains an answer. Although the indicators seem to coincide and expectations are high, the DNA test shows that she must continue her quest to discover her origins and to tear down for good the web of lies in which she has been entangled all her life.

Of course, the lies and concealments are not always as absolute as in the previous stories. Sometimes, as in the case of Julieta, the denial of truth can be much more subtle.

\section{Half Truths}

The Case: Julieta always knew that she was adopted but she never accepted it. In her youth, she has a breakdown that propels her search for her birth family.

The Characters

Julieta (the adopted daughter)

Norma (the adoptive mother)

Otilia Ríos (the birth mother)

Marina (Julieta's biological sister)

Emilce (another biological sister)

Mercedes Yáñez (head of the Office of Human Rights of the Civil Registry of the City of Buenos Aires)

Elsa Freijo (attorney for the Grandmothers of Plaza de Mayo Association)

Despite her thirty-eight years, Julieta still looks like a young girl. She arrives wearing leggings and a childlike smile. We exchange greetings and she immediately begins to talk, her manner natural and frank.

Julieta: I always knew that I was adopted . . . [Her words ring out and seem to echo against the walls of the bar. She quickly modulates her voice.] Well, actually, they told me in so many words when I was four years old, but apparently I started asking questions right after my brother was born when I was two. Even though I always knew it, though, I was never able to accept it.

Viviana Bernath: Why not? What was it like?

J.: I acted like it wasn't so. I never told anyone, none of my friends. I never talked about it even with my brother... I was so afraid. My folks adored me, but just the same, I was afraid they would abandon me. . . It's not an easy thing to talk about. Because they didn't lie to me. They always told me the truth, that I wasn't their daughter. I was the one who lied. I wanted to pretend I was a normal girl, you understand? Like any of my school friends. At the same time, inside of 
me, I felt that it wasn't true, that I was different, and above all, that I had to be perfect so that they wouldn't leave me...

V. B.: Did they tell you that?

J.: Not in those words, not at all. I was my dad's favorite and my brother was my mom's, but no, they never treated us differently. But there were differences; I could feel them. Even if it was in a good way. I don't know if I'm explaining it right...

\section{B.: For example?}

J.: For example, Norma, my mom, always said that it was thanks to me that my brother was born, that thanks to me we were the family that we were. Because before they adopted me they had tried for several years to have children, but they couldn't. And then they adopted me and not long afterwards my mom got pregnant. And she would tell me that it was thanks to me. Do you see what a burden that was for a little girl? It's a hard thing when they make you the one who's responsible for the family's happiness. It's too much... And when you're little, you don't completely understand the things that grownups say or what they mean... Because what I understood, what I believed, was that in order for them to have me with them, I had to do everything right, to be perfect. I had to be the best student, get the best grades, be the best athlete, be the one who was outstanding in everything. I had to make them proud of me, but not just the way any parent wants his child to do a good job; no, to me, what I felt inside, it was my obligation, what I owed them for their kindness. Kindness is not an easy thing to talk about.

V. B.: But they also told you that it was thanks to you that they had a family...

J.: Yes, but it's like a coin that has two sides to it, both heads and tails, because they thank you, but that, in turn, gives you an obligation. I wanted to give the impression that everything was normal, but then I started to isolate myself, to close myself off, because you can't keep lying all the time to everybody. That's a hard thing to keep up ... I didn't tell anyone that I was adopted. [She stops for a moment, staring into the past.] Then when I was a teenager I had fewer and fewer friends. I didn't go out, I didn't go dancing, nothing. Because my lie couldn't hold up any longer, and I couldn't handle the truth that I was adopted. . .

V. B.: And your parents, they didn't encourage you to tell your friends the truth?

J.: No, they never mentioned the subject. As far as they were concerned, it was enough that they hadn't hidden it from me. Start over with a clean slate, everything's just fine. Like it was a secret, but not because they asked me not to tell. Some things are just implicit: I lied, and they never said anything to clear things up...

V. B.: When did you decide you wanted to find out about your past?

J.: When I snapped. I had enrolled in the university. I began studying law. 
But even though I had always done really well at everything, I couldn't handle my studies. It was as if something inside of me had burst. I wasn't attending classes, my absences were piling up, and I wasn't keeping up with the work. And forget about the exams; I would tremble like a leaf and my mind would go blank. My entire first term (four months) was like that... Then I began therapy. And it was during this time that one day I unexpectedly saw that ad by the Grandmothersthe one where a boy looks at himself in the mirror and asks himself, "Am I Pedro? Do I even know who I am?" And it hit me hard, because I really identified with that. That was what was happening to me: I didn't know who I was.

$V . B .:$ And then you decided to find out?

J.: Not right away. It took me a while, but I finally got in touch with Grandmothers and later with CONADI-the National Commission on the Right to Identity. They helped me, even though I wasn't the right age to be a daughter of the desaparecidos. You can't imagine how good it felt to realize that I was going to be able to find out who I was. Because even though I was studying law-by this time I had conquered my panic and gone back to school-I had no idea that the possibility existed of tracing my birth family. Besides, my parents had always told me that they didn't know who my birth mother was or why she had given me up. They said that no one had access to that information.

V. B.: They denied the possibility or they didn't know about it?

J.: No, it wasn't that they didn't know about it, at least in my mom's case, because she is an assistant social worker on the Council on Children and Family. The paperwork for my adoption probably went through quickly for my parents, because my mom worked right next door to the adoption office, and everybody knew her. So she knew very well that the files weren't sealed, and that everyone has the right to know who he or she is.

V. B.: So that showed you that Norma had a problem with the subject.

J.: That, and the way she reacted when she found out that I was looking for my birth mother. Norma couldn't tolerate the fact that my biological mother could have chosen to keep me and raise me instead of her. It sounds really crazy, but at that moment, when I saw her reaction and realized what she was feeling, that was the first real turning point in my life. Norma had always told me that she and I had a very special bond, something almost supernatural. That we had been together in another life, as if we were predestined to be together again in this life. And then, when she became so angry because I was looking for my birth mother, I felt that she really did think of me as her daughter and also that she was the one who was afraid of losing me. And that was fantastic, because all of that burden that I used to carry began to disappear.

V. B.: But you continued your search just the same ...

J.: Yes, because I needed it. I needed to find my mother, at least, to meet her, to find out where she came from and why she didn't raise me. And I was lucky 
with that, although I have a knack for being a detective. In fact, I think that all of us adopted kids do. I remember when I was little-I don't know, around nine or ten years old-I used to go through my folks' dresser drawers, trying to leave everything the way I found it. I tried to find documents, information about myself, and then took great care when I put things back, so that no one would notice... Anyway, the thing is that I decided to follow the advice of Dr. Elsa Freijo, so the first thing I did was to go to the courthouse to find my file. But I didn't find anything that told about my origins. There were just documents about my adoptive parents, an environmental report, a floor plan of our house, paystubs from Norma and Edgardo's jobs, just the required documents that they ask for in these cases. So I would have to request the information from the Civil Registry office. And there were my certificate of live birth [Julieta now appears to be reciting from memory], the original birth certificate, and the adoption certificate. On the birth certificate it said that Otilia Ríos gave her daughter in adoption, in writing, and she signed in her own hand that she surrendered the baby girl. The certificate also stated my mother's age, that it was her first child, and that she was from Salta. And that the baby's name was Maria Isabel. The birth took place in the Ramos Mejía Hospital in Buenos Aires. When I read the paper I understood that my biological mother had given me away on the very day I was born.

V. B.: That made an impression on you...

J.: Yes, very much, but not as much as learning my original name: María Isabel. I couldn't believe it, because that was exactly the name that I liked best. When I was little, and I read magazines or watched TV, I was always fascinated by Queen Isabel [Elizabeth] of England. I don't know why, but I always wanted my name to be Isabel. A coincidence. . . [She pauses for a moment, but then continues her story.] With the information from the certificate, Mercedes Yánez, the head of the Office of Human Rights of the Civil Registry of the City of Buenos Aires, looked for women of that name and age who were born in the city of Salta. There were many residents of that province who matched those criteria, because Ríos is a very common surname in Salta. Then she decided to first locate women with that first and last name who resided in Buenos Aires, since according to the birth certificate, that was where I was born. She found three women. One of them, because of her age, appeared to be the one we were looking for. One bit of information that seemed important was that, according to the documents for that Otilia Ríos, her mother's name was Isabel.

$V$. B.: So now you had the information...

J.: Yes, but having the information and actually doing something about it ... [She laughs at herself.] Mercedes had to push me a little, because I was stalling. I think I was feeling pressure because of Norma, who was very sad, crying over any little thing... But I finally gathered my courage and wrote a letter to Otilia. I sent it by certified mail to the address that Mercedes had found where she sup- 
posedly lived. The letter didn't say anything except to ask her to get in touch with me. My first surprise came when I read the delivery receipt. Otilia's signature was clear, and it was exactly like the one on my birth certificate. On both of them the dot on the " $i$ " came ahead of the letter; it was unquestionably the same. After that I could relax, because I was sure that it was the right person. A few days later, I received a call...

\section{B.: From Otilia?}

J.: No, my sister called, one of my sisters. [She corrects herself and a smile begins to appear on her face, but the smile is gone when she takes up her narrative once again.] It was Marina. She told me that she was a daughter of Otilia Rios. She said that she had found a letter in her mother's house asking her to get in touch. She lived in Salta and she had come to her mother's house in Buenos Aires to take care of her because she was sick. Later I learned that when my mother received my letter she tried to commit suicide, and that was the reason why Marina had made the trip there from Salta. During that phone call I told Marina my story and, so that she would believe me, I offered to mail her a copy of my birth certificate showing that Otilia Ríos had given up her baby girl in adoption. She would recognize the signature. Marina told me that her mother had never mentioned that she had given birth to a daughter earlier. She promised to speak to her, to ask her. Marina was the second of the four children that Otilia had after her marriage.

V. B.: And she kept her promise...

J.: Totally. Just as soon as Otilia recovered, she confronted her and harassed her until she confessed and told her about my birth. Then Marina called me immediately to confirm that I was right, that we were sisters-half-sisters. She also told me about the suicide attempt, so I didn't want to meet Otilia right then. I thought I should give her time to get used to the idea. If a letter was enough to trigger a suicide attempt, I didn't want to imagine what she might do if she actually saw me. In 2006, on Spring Day [September 21], we spoke on the phone for the first time. We stayed in touch via telephone for almost a year. One day I was feeling curious and wanted to see where she lived, so even though it was some distance away, in a rather dangerous zone, I went there. When I arrived, I asked for her, but she wasn't home. One of her sons let me in-that is, a half-brother of mine. When I saw him I had the sensation that I was meeting someone whom I loved a lot, had always loved, and I wanted to be there with him, to ask him many questions. But I also knew that I had better keep quiet, because I was sure that Otilia had not told her other three children about me. I told him that I was a relative from far away. But I left without seeing her. After that I called her on the phone again and told her that I needed to see her. We agreed to meet in a bar. A friend of mine, Soledad, went with me. I was kind of afraid that I wouldn't 
recognize her, but as soon as she walked in, I could see that that would have been impossible: we look exactly alike. That was a very strange meeting...

V. B.: Why?

J.: I don't know; except for looking alike, we didn't make a connection. It was as if our roles were reversed; she couldn't stop crying, and I was consoling her. I couldn't ask her many questions, but I was content with seeing her face, knowing what she was like, and having her tell me whatever she could. Furthermore, that one meeting was enough for me to begin to accept myself as a person born from the womb of another human being. It was incredible... I learned that day that Otilia had come to Buenos Aires from Salta and worked for a family in their home. She started dating a man who worked in a bakery nearby. When she became pregnant and told him about it, he confessed that he was married. His name was Manuel Galván-or at least, that's what Otilia told me. After that day, we continued to talk on the phone. I would call her at the home of Emilce, my other sister, who didn't know anything about me. I was tempted to tell Emilce the truth, but I couldn't bring myself to do it, because Otilia wasn't ready to come out with her story. But one day I couldn't stand it any longer . . . At first, Emilce froze up, but the information that I gave her was so accurate...

V. B.:. . that she had no other choice but to believe you.

J.: Exactly. And I can't explain to you how relieved, how happy I was . . . Meeting each one of my siblings was special. You know how when you're going to meet the boy you like for the first time? Those butterflies in your stomach?

V. B.: Yes ... [I tell her with a smile.]

J.: Well, that's the way I felt with them. There was so much emotion, so much happiness. I had brothers and sisters; I couldn't believe it! Because I was looking for my mother, but I found a family. . . Not because of Otilia .. .

V. B.: With her, you couldn't make a connection ...

J.: We see each other, we talk, but there's something inside of her . . I think that she still can't forgive herself, no matter what I say. Maybe eventually . . But with my brothers and sisters it's completely different. With them I really was able to form a relationship. It isn't an easy thing to talk about, adoption . . . It's like you're split in two, pulled in different directions. I don't know how to explain it. You have this weird guilty feeling, because you wish that things could have been different. For example, for many years I wished that my biological parents had raised me. But now, I don't. Now I think that what happened was a good thing, although of course I would want to change the way my parents handled the subject-my adopted ones, that is-or the things they never told me. That, I would change. But not the fact that Norma and my dad raised me ... . [She sips her coffee, trying to find the right words.] For example, as soon as I learned the story and met Otilia and my siblings, all that business with the phobias, the 
mirrors-with defining my self-was gone. Now I know who I am, who I look like, where I came from. And I can also see things in myself that I got from Norma or from my dad. I move like them and my facial expressions are like theirs, and besides, I'm following in my dad's career footsteps, but with a social orientation that I got from my mom. Everything is much clearer now ...

V. B.: Do you think that finding out about their origins is something that all adopted children need to do?

J.: I don't know. . . that's the way it worked for me. It was what I needed . . It was right for me, but I don't know if it would be right for everyone. It seems to me that it would have to come from inside you. What I do think is that people have rights and that you have to know that you have them, that no one can take those rights away from you. After that, you can decide...

Then there is the guilt that you feel. It's as if just by finding out, you're betraying the ones who raised you and gave you everything. It's complicated. Because what you don't realize, what you're unable to perceive, is that the ones who are afraid of being abandoned are your adoptive parents. Because I grew up with the fear that I would be abandoned again, so I didn't notice Norma's fear, for example, that I would leave her for Otilia. And that is something that never would have happened... I knew that, regardless of how wonderful a connection I might have had with Otilia. No one can erase all those years of love. I think... [She pauses for a moment.] I think that the point is, it's not a case of Otilia or Norma; it wasn't that I had to be perfect or they would abandon me; I'm finally beginning to understand it...

V. B.: The "either/or" has to be changed to "both/and."

J.: Exactly. I have my brother by adoption, and I have my half-brothers and half-sisters, you see? I love them all. And Otilia and I don't have that mother/ daughter communication that you hope for. That's the way it is. And I adore my parents ... Again, I don't know if all adopted children have to find out about their origins, but it does seem to me that they could be saved from a lot of suffering. Just imagine, I'm nearly forty, and I'm just now beginning to learn who I am. That took way too long, didn't it?

Yes, it does indeed seem that it took too long.

After a while we say goodbye and I watch her leave in her leggings, with her appearance of a young girl just starting out in life. It occurs to me that that is, in fact, the case; that in spite of her age, it hasn't been very long since Julieta began to live.

Julieta knew that she was adopted even when she was little. It was not an intuition, or an inference, or a discovery. Her parents' actions were very unusual for that time, when there was still considerable prejudice, both personal and social, regarding adoption. It is to address that issue, Dr. Freijo explains, that 
today's adoption laws state that all adoptive parents should make a commitment to inform their children about their biological origins. It is interesting to note, however, that the law asks the adopters to promise to reveal the truth, but it does not force them to follow through. Clearly, Julieta's parents were ahead of their time. Their attitudes and actions were in accord with what the legislation now advises, but that does not mean that they were comfortable with the situation. In Julieta's case we are getting into subtle mechanisms of denial. Although we cannot accuse anyone of outright lying, we can indeed characterize the events of this story as a game of appearances, in which everyone knows the truth (that Julieta was adopted) but acts as if it were not so. Everything that the family-and Julieta in particular-does not say out loud becomes a volcano that erupts in the end.

When she reaches adolescence, all the pretense of having biological ties to her parents becomes impossible to sustain. Julieta's withdrawal and her isolation from the outside world are the first defense mechanisms that she employs in order to continue with the game of appearances, to keep up the implicit pact of silence. Her efforts, though, are all for naught. There is no way for her to construct her identity on that basis. The ensuing crisis, therefore, is inescapable; she begins to see that only by owning her adopted state and learning about her biological past will she be able to put the pieces together and recognize herself.

Of course, Julieta herself recognizes the magnitude of that moment when, having already begun her therapy, she saw that Grandmothers of Plaza de Mayo ad, whose questions_- "Am I Pedro? Do I even know who I am?"- produced a shock of recognition. Though it was not immediately plain to her,that was the point of no return in her search.

This is no coincidence, nor is it trivial. It is well known that during the last military dictatorship in Argentina, many-perhaps hundreds-of young children of the desaparecidos, often born while their parents were in detention camps, were systematically appropriated. The Grandmothers of Plaza de Mayo's search for their lost grandchildren accomplished their purpose in some cases, as we have seen in the story of Pedro Sandoval Fontana ${ }^{3}$ and as will be evident in that of Martín Amarilla Molfino. Their efforts did much more than reunite biological relatives, however; they also raised awareness concerning the right to identity. Julieta's case and that of Aída, below, are examples of a phenomenon that appears to be peculiarly Argentinian.

3. Pedro Sandoval Fontana, raised as Alejandro Rei, was found in 2006 to be one of these stolen babies. DNA tests confirmed that he was the biological child of Pedro Sandoval and Liliana Fontana, two young activists who "disappeared." Their bodies were never found. Trans. 


\section{Do You Know Who You Are?}

The Case: Aida has always wanted to know who she is. Recently, following the death of her adoptive mother and stimulated by the campaigns of the Grandmothers of Plaza de Mayo and the HIJOS organization, she decides to take up the search.

\section{The Characters}

Aida (the daughter)

The mother and father who raised Aida

The doctor

The doctor's wife

Mercedes (head of the Office of Human Rights of the Civil Registry of the City of Buenos Aires)

Patricia (member of Raíz Natal)

Juan Carlos (possible biological brother)

Carmen (possible biological mother)

Aída: I am forty-two years old and I was appropriated.

Aida's stark statement shows no shadow of doubt in her mind. She takes quick sips of her coffee and never releases the cup handle, as if clinging to a talisman.

Unlike other interviews, this one is simple, almost spontaneous. When I approach Raiz Natal and ask if I may converse with some members of the group, she immediately volunteers. As if bursting with the need to tell her story, it is Aida who begins the dialogue. After pausing for a moment, I ask my first question, more as a formality than to stimulate her response...

Viviana Bernath: When did you first begin to doubt that you were your parents' biological daughter?

A.: Honestly, I don't have any recollection of my earliest doubts . . but what I can tell you is when and how I found out that I hadn't come from my mother's belly. [Aída declares this firmly.] I was very little; I must have just turned five, because I remember that my sister was born shortly after. I was at my grandmother's house and a fat old woman that I didn't know showed up. I was eating a snack when she came into the kitchen, sat down beside me, and said something that made me burst into tears. I don't remember her exact words, but I do remember what I felt, the sensation of infinite anguish. I cried inconsolably. In the end, my mother had to explain to me that I had not been born from her belly. The truth is, it wasn't that old witch's place to tell me that. I kind of short-circuited. If this episode had never happened, I don't know when they would have told me that I wasn't their biological daughter. [She stops for a moment, but then quickly continues.] Shortly afterwards, we went to the home of a seamstress who used to 
make little dresses for me. She lived far away. While I was there, I was told that I was going to have a little sister that day. Then they took me back home and I stayed with the woman who was paid to take care of me. That night, my parents came home with a baby girl in their arms. I was a big girl then, and I knew very well that my mother had not been pregnant. No one had to tell me that, just like me, she was not my mother's daughter. I've tried many times to locate the house where that seamstress lived. I can describe it perfectly; I've dreamed about it a thousand times. I think that it was in Grand Bourg or Villa Celina. It drives me crazy, not being able to remember...

V. B.: Your parents had not had children of their own...

A.: My mom was older when she got married. At first, neither she nor my dad wanted to have children. When they decided that they did want them, she was forty-two years old. When she didn't get pregnant, then she started to have treatments. When she finally conceived, there were complications, she lost the baby, and then she could never have any more children.

V. B.: What was your childhood like?

A.: There were just the two of us, two sisters. My mom was an excellent mother, a loving woman who took very good care of my sister and me. My dad spent a lot of time with us too. He adored us.

V. B.: At what point did you start to ask your parents about your biological mother?

A.: People who knew me when I was little say that from a very young age I was constantly asking my parents who my mommy was. They would always tell me the same story: my mommy had died giving birth to me. There wasn't any man around claiming to be my father. I was all alone in the world and the doctors were going to send me to the Foundling Hospital [Casa Cuna]. They gave me the impression that it was horrific, a hellish place. Later, my aunt, who was a psychologist, and a woman friend of hers-a doctor who later became my pediatricianheard about me and intervened so that, instead of being transferred to the Foundling Hospital, I was given to my parents. In all the documents, I appear simply as their biological daughter. But what I remember best is what happened to me when I was an adolescent. I must have been fourteen or fifteen years old. I hounded them with questions, asking directly where I was born. Who the woman was who had died in childbirth. Why she had died. They always told me that they didn't know; they explained that in those days many women used to die in childbirth. Back then I even felt shame whenever I happened to see a pregnant woman. I had to turn my head, to look the other way. I felt responsible for my mother's death... Another bit of information that they had told me when I was little was that five days had passed between my birth and the day that they took me home. My birth was registered as taking place on July 23. The strange thing is that I always got sick a few days before my birthday. For forty years, I got sick somewhere around July 19. It's incredible how powerful words can be; it's as if my body knew the truth 
before my mind did. When I was a teenager I couldn't stop thinking about those five days. I felt guilty about my mother's death. I insisted that my parents tell me what had happened during those five days-where I had been. This anguish cost me several suicide attempts...

Talking to my parents was very difficult. My mom would start to cry and wouldn't answer me. My dad would get angry and turn violent. Both of them, with their responses, made me hold my tongue.

At that time I was in therapy with a psychologist, who did nothing but try to convince me that I should stop nagging my parents with irrelevant questions. She did succeed in getting me to stop hounding them for a while. But on the inside, my agitation was growing. I felt that everything about me was a lie. I needed an answer about what had happened. Any answer. I didn't care what the answer was.

V. B.: When did you begin to make a serious search for your biological mother?

A.: I always knew that I hadn't been adopted. I knew they "obtained" me. They made excuses, saying that in those days it was very difficult to adopt a child, that it took many years and that they wanted a baby quickly. And I had no reason to doubt what they were saying. It wasn't until the Grandmothers of Plaza de Mayo came along that I realized that everything that is not an adoption is illegal and that my own case was one of appropriation. There was a good reason why, when the first few of the Grandmothers' cases were made public, it caused a furor in my house. My dad denounced the Grandmothers, saying that those women were destroying people and homes. Because I wasn't the right age, I knew that I was not connected to the desaparecidos, but his attitude made me think about what they must have done in order to obtain me.

When I was twenty-five, my mom got sick with cancer and died. A few months later, my dad went to live with another woman. At that moment, it seemed to me like a door was opening. . . [Aída finishes her coffee, sets the cup down and immediately pulls a cigarette out of her purse and lights it avidly.] One day I was taking a bus downtown from my house and, one block away from the Military Hospital, the graffiti on the Las Esclavas School caught my eye. It said, "Do you know who you are?" and was signed by the Hijos de Desaparecidos [Children of the Desaparecidos] group. When I read those painted words, I started asking my dad again how they had obtained me. But he told me nothing. Several years later, in 1997 or '98, the Grandmothers launched a very aggressive campaign, centered on people's personal doubts about their identity. And even though I knew that it was impossible for me to be the daughter of desaparecidos, I went to see them and told them my story. They referred me to the Human Rights office. There they asked for my birth certificate, but since it showed me as the biological child of my parents, born in a private home, and we knew that all that data was false, they weren't able to extract any information. They suggested that I try to find out in 
what hospital I was born. My dad, who was the only one who knew anything for sure, was still yelling at me not to stir things up...

One year later, in '98, something happened that was very important to me. It occurred to me to look in the phone book for the doctor whose name was on my birth certificate. The certificate also said that I was born in a private home-my paternal grandmother's house in Villa Ortúzar. My sister's documents gave the same address.

I called the number. A man answered. I told him that I was looking for soand-so, a medical doctor by profession, license number such-and-such, which was listed on my birth certificate. It was him. He explained that he was working at the Álvarez Hospital at the time as a shift chief and that his functions included signing only certificates of death, not birth. Ironically, he asked me if the document I had in my hands was a birth certificate or a death certificate. I reacted badly and told him, "No, Doctor, I'm alive." But then, even though the man had made me angry, I felt that I had to get more information from him. It occurred to me to mention my aunt, the psychologist, and her friend, my pediatrician. I had always figured that they had intervened to help my parents obtain me. And at that moment the doctor changed his tone of voice. In a much calmer tone he answered that he knew both of them very well. But he continued to insist that he had never signed a birth certificate. That was when I realized that I was talking to the right person, not only because of his license number but also because he actually knew my aunt. If the information was true, then I was born in the Alvarez Hospital.

Unfortunately, I couldn't consult my aunt because she had died. She fell ill with cancer in the late 1970s. So then I decided to look for that pediatrician, my aunt's close friend, who had also been my doctor until I was ten and my sister's until she was five. I made contact and she tried to dodge me. She said that she didn't remember me.

Even though I was convinced that the correct procedure was to continue questioning people, a friend that I was talking to warned me that I should be careful about asking people questions. It was one thing to look for answers within my own family, but quite another thing to compromise professionals who could lose their licenses if they revealed the information that I was looking for.

Her words frightened me and made me back off from a search that was turning into an obsession. Besides, by then my dad was very angry with me and hardly even wanted to see me. I decided to wait until he calmed down and decided for himself to tell me everything that he knew. But he died in 2002 without telling me anything. Both of my parents had died without saying a thing...

Shortly after that, when I had gained a little control over my fits of crying over my father's death, I took up the search again. But clearly, it was not the best moment. A week after I made the decision I fell into a profound depression. I made a suicide attempt, my life was in danger and I was hospitalized... I recovered in 2006. I'm all right now. 
That year was the thirtieth anniversary of the military coup, and I decided to go to the march that the human rights organizations and the political parties had organized. It was the first time I had ever gone to a march. I didn't go when Argentina won the World Cup or for any student political movements. I never went to anything for any cause. That day, though, I went to the plaza. I needed to talk. That was how I fell into conversation with a woman with a white scarfwith one of the Grandmothers. She saw my anguish and she took the time to listen to me, to contain me. I told her that I, too, had been an appropriated baby and that, for that reason, at our house I wasn't allowed to talk about the dictatorship or the desaparecidos. They were afraid that those stories would feed my fantasies. She suggested that I go to the psychological care center that the Grandmothers have now. A few days later I walked into the office that she had told me about. A psychologist talked with me. In the interview, I told her that I was very distressed because I wanted to find out my true identity. I knew that I was too old to be the child of a desaparecida, but that I had frequent fantasies about being one. In the early sessions I began to narrate my identity problems. The subject of my search came up right away, and my therapist mentioned that she had heard about a group of people who were searching for their biological identities and that they were very serious about it: Raiz Natal. She suggested that I go see them. Following her advice I went there. They gave me a huge, warm welcome. They explained that there was a Human Rights office in the Civil Registry of the City of Buenos Aires. Mercedes worked there; her primary task was to help people who had been adopted or whose identity had been substituted to find their biological families. She did it by investigating the documents. I had to go there and take my birth certificate. I went to see her. She opened the door of her office and listened to my whole story, patiently and rationally, without interrupting. Then she carefully read all the information contained in my birth certificate. The first thing she asked me was whether anything that a relative or friend had said had given me a hint as to what hospital I was born in. I told her that I suspected it might have been Álvarez, because of what the doctor whose name was on my birth certificate had said. I went to the Álvarez Hospital, but the doctor that I had talked to wasn't in any of their records. He had lied about everything. Furious, I went to his house. That was when I felt that everything was falling apart. The doorman told me that the doctor had died six months earlier. He told me that the widow was still living in the house. Trying to hold myself together, I wrote her a letter. I gave her a brief version of my story and of the search that I had undertaken. I told her that I knew that her husband had known my aunt and my pediatrician. All that I needed from her was the name of the hospital where her husband was working at that time. I begged her to believe me, to cooperate with me. I included a photocopy of my birth certificate with her husband's signature.

To my surprise, she answered me within a few days. She called me on the telephone. She told me that when I was born, they were not yet married. She was his 
second wife and they had gotten married in the mid-1970s. However, she believed that she did have an important piece of information for me. She knew that his first wife had been a doctor and was also sure that she had been a friend of my aunt and my pediatrician. The woman worked in the Argerich Hospital. The widow asked me not to bother her again.

Her information was invaluable. I went back to see Mercedes. A new possibility had opened up; maybe I was born in Argerich. Mercedes is a ghost hunter. She felt that this new clue was essential. It felt right.

Through her office, she requested a list of all the birth certificates issued by the Argerich Hospital on the day shown on my birth certificate and for five days before and five days after that date. When the hospital sent it to her, she read through the entire list of births that took place in Argerich during that period. She found birth certificates for three babies who had never been registered under the names shown on the birth certificates. But those babies had really been born, whether they had been registered or not. What could be the reason why their documents had never been processed? One possibility is that their National Identity Documents [DNI] had never been processed and the other is that they were given away and registered under another name.

There were three ghosts. I could be any one of them. Together we analyzed the options. One of them was a boy. Even though anything is possible, it bothered me to think of myself as a boy. I ruled that one out. Two were left. One belonged to someone who had a very common name and surname and since there were many people registered under that name and surname, it was hard to know if she was alive. The third possibility was a baby girl born to a single mother, and the father was unknown. Immediately I said, "That's me."

Without a second thought I set out to find this woman who was supposedly my biological mother. Patricia from Raíz Natal went with me. [Aída takes a long drag on her cigarette and starts to talk more rapidly, as if nothing could stop her now.] But the address we had was wrong and instead of my supposed mother, we found her nephew. We introduced ourselves. Patricia did the talking; I didn't have the nerve. We had shown up out of the blue. The nephew, after listening to us, asked us to wait a few minutes. He went into his house and came back with a photograph of his wedding. It was a family picture; there he was with his wife, his mother, and other relatives. I had barely glanced at it when I spotted one of his sisters who looked like me. I pointed to her; she was even wearing a blouse that looked like one I had.

I am a brunette in a family of blonds. It had never seemed to me that I looked like anybody. The only thing I had in common with my mom was our height-we were both very petite. It hit me hard to look at that photo and recognize myself in it. I was sure that I had never seen that photo before and that I had never been in that place, but at the same time, I felt that I was in that picture. The same haircut, the same way of holding the hands. It wasn't just that she looked like me, 
and that I felt that I looked like her. It was also that this guy who answered the door and who had absolutely no idea about my supposed biological connection had also seen the resemblance. But the woman I was looking for didn't live there. The young man gave us her address. I let three months go by before I went there.

Patricia went with me again. She lived in a terribly poor area, on the road to Luján. The first person we met was Juan Carlos, one of her sons. Again, it was Patricia who did the talking. I didn't feel up to it. Juan Carlos kept looking at me. Suddenly he stopped Patricia and just looked at me. He asked whether I was the one who was looking for my family and when I said yes, he said that I looked just like his grandmother and his cousin. Just the way it had happened several months earlier, Juan Carlos didn't need any more explanations. Just seeing me was enough for him to believe what he had heard. After living my whole life in the fear that nobody would believe me, that people would find out that I wasn't real, for the first time I didn't have to justify anything. Just seeing me, they believed me.

That day I did see her. I told her my story, and she told me hers.

My mother's name is Carmen. She had been a rebellious girl; people said she was the black sheep of the family. In 1958, eight years before I was born, a man had gotten her pregnant. Since she was not married, her parents had thrown her out of the house and had kept her child. They named him Juan Carlos, and figured that at least he could do some work for them. So it was that she didn't raise her son during his early years. Some time later, she became pregnant with twins. When she gave birth, the doctors told her that they had been stillborn. That was when she decided to take Juan Carlos away from her parents' house and move to Buenos Aires. There she became pregnant for a third time. In 1966 she had a baby girl who was born in the Argerich Hospital. She held her in her arms. Since she had lost a lot of blood giving birth, she was sent to intensive care. When she recovered, they told her that since they expected her to be in intensive care for many days and she was in no condition to take care of her baby, a couple was taking care of her.

When she was released from the hospital and tried to claim her daughter, they replied that the couple who was taking care of the baby had disappeared. No one knew where they were; maybe they had left the country. She left the hospital without her daughter. She didn't know where to look for her. She never saw her again.

She told me that a few years earlier she had felt very bad, had been depressed and had relived my birth. Everyone had advised her to forget about that daughter. But she had always hoped that someday I would be the one to go find her.

There is no doubt in my mind that the birth certificate that Mercedes found is that of that woman's daughter. The only tiny doubt that still remains is whether I am really the baby girl on that birth certificate. I'm sure that I am and I'm not interested in having anyone come along and tell me that I'm not . . That's why I don't want a DNA test. We look alike and her story fits with mine. So far, I have never wanted to ask her for a DNA test. I can't bring myself to do it.

Everything fit. The dates fit. What she told me fit with what I had been told. 
A woman who gives birth and they send her to intensive care because she lost so much blood. Since she might die, her baby is given to someone else. The problem is that she doesn't die. Then they lie to her, sometimes saying that her child has died, sometimes-as in this case-telling her that the couple who was taking care of the baby had disappeared.

I had just met her and, for several months, I went to visit her every weekend. I finally realized that it wasn't good for me. Knowing her created conflicts in me, because my mom and my dad were the ones who raised me and I am who I am because of them. What they kept from me was that knowledge that there was another part of what I could be. Maybe if they had told me the truth from the start, I wouldn't have felt the need to search ... [Aída concludes her narrative, practically talking out loud to herself. She takes a breath, as if she's going to say something, stops to think, and finally decides to take her leave without adding anything more.]

Julieta and Aída's stories raise the questions of biological identities and origins in a deep and concrete way. Unlike Mariela, who has still not found what she seeks, or Cristina, who learned the truth and found her family but was not able to meet her biological mother, in these last two cases the search was incarnated in a real mother, one who can see and hear, one with whom to confront one's own identity. The dreams, the illusions, the fantasies became flesh and, as so often happens in life, they were not at all what was expected.

Even so-and transcending by far the actual results-each woman feels that it was (and still is, for Mariela) imperative that she set off in search of the truth. None of them regrets having done so.

\section{Notes on Identity in Our Culture}

The stories we have heard seem to prove that the search for one's biological identity is, for those who do not know it, almost a necessity that brings a measure of peace to one's inner conflicts. The construction of identity, however, is much more complex - and not just in cases of adoption, substitution of identity, and appropriation. My conversations with specialists Carmen Gravino ${ }^{4}$ and Eva Giberti ${ }^{5}$ gave me the opportunity to explore several aspects of the matter.

4. Carmen Gravino is a social psychologist educated at CAECE University; a psychological consultant specializing in personal development (Instituto Superior de Ciencias Humanas y Sociales); and coordinator of Raíz Natal's Workshop on Identity since October of 2006.

5. Eva Giberti is a psychologist and a social worker (University of Buenos Aires); Doctor Honoris Causa in Psychology from the National University of Rosario; a university professor; coordinator of the "Victims against Violence" program of the Ministry of Justice, Security, and Human Rights of Argentina; and president of the Advisory Commission for the creation of the National Adoption Registry. 
To lay a foundation for the interview, I sought to begin with the very term that had brought us together.

Viviana Bernath: How can we define "identity"?

Carmen Gravino: A person's identity is the expression of an open process that is constantly in flux. The biological mechanisms of the body interact with the person's psychological and social life within this process. The construction of identity begins with our everyday connections to the people who are closest to us. As we grow, our range of relationships widens. The whole of one's interactions, with both the physical and the social environments, is unique to each individual and impossible to duplicate. This allows us to conclude that identity is unique to each person and that this distinction is the result of the way in which each one carries out his or her own process.

V. B.: Is it customary for those who were not raised by their biological family to search for that family?

Carmen Gravino: Social norms today dictate that children should be raised by their biological parents. It is a cultural matter. It would seem as if, in our society, a person who was not raised by his or her biological parents is not a complete human being. That is one reason why adopted children are distressed when their schoolmates call them "adopted": they feel attacked because they feel abnormal. In our society, being adopted is seen as an abnormality. When a child calls a friend "adopted," he is reminding him that he is different from the rest. She is giving her a mark of shame.

Adopted children also awaken special feelings in adults-for example, an overwhelming tenderness. But that additional tenderness backfires; the adult is also proving to the adopted child that he or she is different.

We may conclude that being an adopted child in this culture means, at the very least, being in a position that is not the same as that of a biological child. This model of affirmation induces many adopted children, or those whose identities have been suppressed and who have been registered as if they were the children of other parents, to wonder at some point, "Who am I? Am I a 'son' or 'daughter' even though my biological parents didn't raise me?" The search is absolutely a culturally defined concept, closely linked to the idea that it is the biological mother who should care for and raise her child.

Eva Giberti: Even though we could list a number of examples of subjects who seek knowledge of their origins, these are only a small minority among those who were adopted or whose identity was substituted. Further, of those who have the opportunity to read their files, very few actually go and seek out their biological families. In particular, those who have had access to psychotherapy and have analyzed the option of reading their files almost never materialize an actual encounter with their birth family. It could be said that, for them, it is good to go through a period of wondering, "Who were the two 
people who made me?" but it is certainly not indispensable to know who they were or to meet them in order for that adopted subject to form an integrated personality. Psychotherapeutic work may help to make this period of questioning or search less painful. With therapy, many conflicts can be overcome more successfully.

This is what is called, in psychoanalysis, a "complementary series." A subject may have gone through or be going through a traumatic situation such as, for example, wondering about his or her origins, with that feeling of "I don't know where I came from." Throughout people's lives, however, they experience a variety of phenomena and events that intertwine to make those people the individuals that they are. If the question of origins is successfully woven into the life of a subject as just another of the conflicts that arise from the mere fact of being alive, it would not seem to be necessary to know who one's birth parents were or to meet those who, by some design of fate, happened to join together to give birth to a child that they then turned over to others.

V. B.: Who are the ones who search?

Carmen Gravino: Potentially, people who search for their biological identity may be subjects who have been told since childhood that they were adopted; subjects who were turned over, outside of the legal system, to foster parents who registered them at birth as their own (we will call this group "registered subjects"; they are also known as persons whose identities have been suppressed or "substituted") and who learned only in adulthood that they are not the biological children of the parents who raised them; and finally, subjects who realize intuitively that they are not the biological children of the parents who are raising them, even though those parents persist in denying it.

The initiative to search may be found in any of the cases mentioned. Now, in general, those who wonder about their biological family need to actually meet them and hear their version of the story of how they gave up their baby. If they were adopted, they are not satisfied just to read the files; if they were registered, it is not enough for them to hear from their parents how they obtained their child. From the outset of the search until the day of meeting, the process is full of loose ends and plateaus. For a while the search progresses and for a while it stalls. Most of those who search do so without meditation, almost at random. They ask questions in hospitals, they talk to doctors, they go to the neighborhood where they suspect that they may have been born. The real difficulty emerges when all that is left is to meet the birth mother. At that point, searchers frequently hit a brick wall. They are afraid. It takes an intense inner battle to break down the barrier and step forward to meet, face to face, that person that they longed so much to find. The specter of rejection, of abandonment, makes its reappearance. For those who begin the search, it is best that they reach their goal. To bring closure to their story, they need that meeting. If 
for reasons outside their control the meeting cannot take place, then the person who is searching needs to feel that every possibility has been exhausted and that there is nothing more that could have been done.

V. B.: What is the average age of people who consult you?

Eva Giberti: We would have to differentiate between the age at which the adopted or registered children are presented with the dilemma of their origins and the moment when they begin the search or decide to do so. Some ask themselves the question about their origins when they are about ten years old; in these cases they may even have emotional attacks of wanting to know who they are. Others begin their questionings at the age of twenty-five. It depends on how their lives are going and what conflicts they need to resolve along the way. Some adopted children who receive therapy when they are small show no signs of this concern, but when they enter adulthood, they return to therapy because they become anxious to learn who their birth parents were.

One thing that we do observe frequently is that the axis of the shock that induces adopted children to think about what had apparently never occurred to them before is, in females, pregnancy. It is at this point that a young woman begins to ask herself about her origins. She knows that her child will not look like her adoptive mother, father, or grandparents. The child will look only like her and like the father. What this future mother states that she wants to know is how her own background will affect her child. Who were her ancestors? What is the DNA of the mother to whom she was linked by the umbilical cord? What is the DNA of that birth mother whom she remembers every time she examines the knot of her navel, a representation of her own true origins? Because no one can be unaware that the presence of that mark in the middle of the belly draws one to fantasize about that woman who carried a child within her for nine months. Of course, the only human beings who had no navels were, quite simply, the only ones who had no ancestors-Adam and Eve. Everyone else has a navel, which explicitly reflects the subject's provenance, and that is the real question that bothers adopted children: Where did I come from?

Thus, when a woman becomes pregnant or feels the desire to procreate, she feels the greatest need to know whence she came. In addition, the very context induces her to ask herself questions. The obstetrician asks her directly about her family medical history - whether anyone has diabetes, high blood pressure, or cancer, for instance. It is then, at her very first visit to the doctor, that both she and the baby's father find themselves in a conflictive situation. The conflict emerges when she has no answers to the questions.

This dilemma does not arise among adopted males who are soon to be fathers. In a patriarchal society, when the adopted child is the father of the unborn baby, both the obstetrician and the future parents tend to be indifferent to his medical history and biological origins. 
V. B.: We see this also in the fact that those who search for their origins focus on finding their birth mother and not their biological father ...

Carmen Gravino: True, most of the searches are oriented toward the mothers and not the fathers. This reflects the fact that in our society it is the mother who is supposed to always protect her child; she is the unconditional figure. In our culture, the word "mother" drags in its wake a tangle of social conditionings that contributed to converting that primitive act of giving birth into today's concept of what a mother should be: a fountain of love, supposedly unconditional; devotion that is assumed to be absolute; and utter unselfishness toward her children. It is a proven fact, however, that the act of giving birth does not automatically turn a woman into that ideal mother to whom society assigns those responsibilities. Reality often shows us that some women are unable to meet the requirements that society imposes upon them in order to adequately fulfill their role. This may be due to their life histories, to immaturity, or perhaps to their financial situation. When a woman fails to meet her social requirements, whether on her own account or due to external pressures, she decides to delegate that function to another person who is supposedly better qualified for the task. This is where the role of a mother may split in two. On the one hand, there is the mother who provides the womb, and on the other, there is the mother who fulfills the expected functions prescribed by society.

In our society the role of the father is not homologous to that of the mother. Social consensus establishes different expectations for the two. In order for a man to be considered a father, he must assume responsibility for the child. It would seem that for men, reproduction and paternity are two independent phenomena. For all of these reasons, perhaps, in the search for biological roots the questions are focused on the mother; the father is relegated to the background.

Eva Giberti: People who were adopted often search for their birth mothers because it is hard for them to break away from the profound nostalgia that they feel as a result of the idealization of that union of the flesh. It is a nostalgia for an unrequited, unsatisfied love-that love that they never had, the love of their birth mother. This nostalgia brings the adopted child back, time and time again, to the same question: "Why didn't my mother want me? Why did she give me up? Why did that woman cheat me out of the satisfaction of sharing her life?" These questions are centered on the constant nostalgia for the mother's womb-that perfect place that no one should ever have left, at least in the imaginations of today's culture. It is that uncertainty that torments the adopted child.

What we do not know for sure is whether that is really true or whether we ourselves have created this culture of the uterus, of the womb, and of a mother's self-sacrifice. Culture bears the blame for having blocked the possibil- 
ity of wondering about one's paternal origins. Adopted subjects not only fail to search for the identity of their fathers but also tend to invent paternal figures that are sometimes comic-book or TV heroes, extraterrestrials, or even robots.

It is a fact that in today's world, the role of the father is more important than ever in the life of a child, offering affection, care, and attention. Will this new way of fathers relating to their children displace the predominantly umbilical culture? Will adopted children then begin to search for their birth fathers as well as their birth mothers?

V. B.: In a sense, this could be linked to the question of what the searchers are looking for...

Eva Giberti: The search for origins is valuable only if it materializes as a personal choice-when the choice is moved by the desire. Desire is the driving force that takes people where they're going and never ceases to operate. It isn't magical. The philosophy and the unconscious world of desire are associated with something about which the person has no conscious knowledge. Desire is the thing that steers people's behavior to make them, in the end, who they are.

Knowing this enables us to understand that the true conflict for adopted children or youths consists of knowing what their desire really is. "Do I or don't I want to know about and meet my family of origin?"

In addition, though, the desire of each person is related to knowing who he or she is. And this "Who am I?" is closely linked to who one's parents are and the project that they have for their child. What my desire is depends on who I am. In the case of people who have been adopted, a conflict emerges between the desire that the birth parents may have had for that child that they gave up and the desire of the adoptive parents. How can adopted children resolve the conflict of whether they will identify with the desire of the birth parents or with that of the adoptive parents?

Setting aside those cases in which parents are forced to give up their child due to specific, concrete situations, adopted or registered children who wish to escape from this dilemma should attempt to assimilate the fact that, in their birth parents, the desire to have a child was overcome, overshadowed, or diminished by the desire to give up that child. The birth parents, therefore, had no project for them. Clearly, whenever a birth parent voluntarily gives up a child for adoption, that parent is expressing by that act a force that is more powerful than the desire to raise the child. In those mothers, the desire to abandon their children was greater than the desire to keep them. As a result, the problem for adopted children is essentially how to leave behind the presumed desires of their birth parents and take on as their own the desires of their adoptive parents.

When people try to swim against the current that carried them to a life in an adoptive home, they are headed for a confrontation with a crucial question: 
"Am I where I am because my birth parents didn't want me, or am I where I am because of some circumstance that was beyond their control?"

They may or may not want to answer that question. If they do, then their attitude will be one of investigation of their past. That stimulus will move them toward the possibility of a reunion with their biological origins. Adopted children may meet their birth mothers and realize that the only connection they have with them is the question, "Why did you leave me?" Once they have met, the answer may become less important, because they realize that they really have nothing in common with those women.

To summarize: to know who you are is to know that you owe nothing to the desire of others. Only this knowledge will lead to behaving in accordance with your own desire. "What would my biological parents have wanted me to be?" Only when adopted or registered subjects accept that the desire of their biological parents to give up their children was greater than their desire to keep them will they be able to deal with the desire of the adoptive parents. In the end, where the desire is, that is where the love is.

Carmen Gravino: In a workshop that I coordinate on biological identity, I asked the participants, "Why are we looking for our biological identity? What are we really talking about when we refer to the search for biological identity? Why do we think that it will be helpful to learn about it?"

The majority responded that with the discovery of their biological identity, the history of a blurry or undefined identity would be cleared up and thus closed. That history, in many cases, was infused with lies, family secrets, social or cultural stigmas, etc. In general, people who look for their roots, when they insist that they need to find out about their biological identity, are not thinking merely of their genetic legacy; they are not pursuing scientific knowledge. Their concerns are to understand the reasons why they were given up for adoption, to meet the mothers who brought them into the world, and to find out where they were born.

What they are really pursuing with their search is to tie up their history with a bow, define their situation, know for sure, exercise their right to know the truth. Achieving closure for their history involves finding their place in time and space and knowing who the person is who brought them into the world.

Normally, those who have access to their biological parents are not thinking in terms of making any claims or demands regarding money or surnames, or of abandoning the parents who raised them. Their only objective is to find the answer to a question that, without that answer, produces nothing but pain.

V. B.: This brings us, in a way, to searches that are triggered by lies ...

Carmen Gravino: It is important to realize that, thirty years or so ago, adoptive parents did not customarily reveal to their adopted or registered chil- 
dren the truth about their origins. Many of those who are currently searching for their biological origins grew up in a context that was completely different from that of today. People did not tell their children, "You did not come from my belly." As they search, adopted children need to understand that social codes when they were born were not the same as they are today. In general, the lies that they were told were not meant as an act of bad faith on the part of their parents; they were simply the product of social customs that were in effect in those times. If people who were adopted are able to understand this and avoid becoming angry with their adoptive parents, their search will be much less distressing.

In the present context, it is recommended that parents talk to their children about their origins so that they can assimilate the information gradually and without suffering trauma.

There are many cases in which the adoptive parents choose to hide the fact that they are not the biological parents of their children. This may be due to the fear of losing their adopted or registered children or because they know that some aspects of the process of obtaining the children were illegal. We believe, however, that these children-or adults-have an unconscious perception of this part of their history, when they were taken away from their birth mothers. It seems that they hear the silence of their family members; that silence speaks of something hidden. For this reason, an act of sincerity is indispensable. Only the truth can diminish the risk of a break in the relationship with these beloved sons and daughters.

Whatever the reasons for the decision to hide the truth, deception must not continue to inhabit the bosom of a family. With the truth, parents can recover the respect of their children. They will be giving them the gift of a chance that they never had in the past, the opportunity to choose them as parents.

The facts prove that the search initiative is not dependent on the strength or quality of the bond that has been constructed between parents and children. Many of those who search for their origins have achieved a very good relationship with their adoptive parents. The bonds between them have nothing to do with biology. Obviously, in many homes where children grow up with their biological parents, the families fail to construct solid, affectionate, committed bonds. Problems with relationships are equally common in families with adopted children as in those with biological ones.

One thing that we often observe is that when adopted or registered children have a conflictive relationship with their parents, they tend to blame it on being adopted instead of analyzing the true origins of the conflict. Adopted children frequently argue that they want to meet their biological families because life has been unfair to them by separating them from their real parents. In such cases it can usually be seen that there are problems between children 
and adoptive parents that have nothing to do with biology. It is important to try to keep family conflicts separate from the search for origins-to try to free relationship problems from the determination of biological identity. Family bonds are not based on origins. Domestic violence, abuse, or hostility in the home have nothing to do with whether the children are adopted or biological.

Once the problem of family relations has been cleared up, we can say that what leads an adopted or registered subject to search for his or her origins is the need to know.

V. B.: Carmen, you indicated that, in your experience, the desire for the search for biological identity is for closure of one's history. What usually happens next?

Carmen Gravino: Frequently, when adopted or registered children find their biological families, they do not maintain the connection. One reason for this is the existence of subcultures within a culture. We live in a Western mother culture. But there are certain structures that are characteristic of Argentina, and also of the place in which each of us was raised. Each of us has a mixture of subcultures. When two people from different subcultures meet, they are not always able to make a connection. This is what often happens when an adopted or registered child meets his or her biological mother. They are unable to make a connection. It is difficult to force a relationship between persons from different subcultures. Each of us is rooted, to a degree, in what we were taught, what was transmitted to us. We have a preference for that subculture that sometimes does not allow us to move into a different medium and form bonds within other subcultures. This is probably the reason why adopted children may not establish a link with their families of origin.

The conclusion is that it is not possible to love someone simply because of a title. Being a biological mother is not sufficient to be loved like a mother. Biological links are neither necessary nor sufficient to nurture a filial relationship.

Once they have met, adopted children and biological mothers should think about whether they desire to travel down the road that leads to generating affection. Until that moment, the adopted child had a construct of life in which the biological mother was absent. The premise that all parents must love their children will have to move from theory to reality and be felt, in the flesh, by those involved. After all, who are the real parents? The mother who carried a child in her womb for nine months? The father who stayed up all night when his child was sick or had a toothache? The parent who helped with homework and baked birthday cakes?

During the search process, adopted or registered children frequently displace their adoptive parents in favor of the biological ones. This is not beneficial. In order to accept their histories they will need to rearrange their ideas and reevaluate the role that their adoptive parents played in their lives. 
Sometimes, adopted or registered children who search for their biological parents do not question their adoptive ones; they are able to keep the two absolutely separate. They do not complain about the lies; sometimes they even justify them. They are convinced that their parents did the best they could and would never judge them, because they filled their lives with love. In spite of all of this, they still feel the need to search, to know. Furthermore, in our society, the rise of the Grandmothers of Plaza de Mayo brought with it a need, almost an excessive one, to want to find one's biological identity. Probably, without this trigger, many people would never have thought seriously about searching for their origins. The abundance of available information related to biological identity has awoken a great deal of curiosity.

V. B.: The Argentinian experience is different in this sense?

Carmen Gravino: Definitely, in Argentina the search for biological identity has reached a level of development seldom seen in other countries. Our desaparecidos, and the determined search by the Grandmothers for the children of the desaparecidos, were the elements that fixed in our social imagination the importance of the right to identity - that guarantees to every individual a name and surname and the knowledge of his or her biological parents and family history-and in consequence, knowledge of one's biological identity. Undeniably, it was the Grandmothers who caused the boom in the search for biological identity.

Many people, even though they knew for sure that they were not the children of the desaparecidos, identified with them just the same, having been inspired in their own searches by the Grandmothers' campaigns. Sometimes they have intense feelings of abandonment associated with the violent kidnapping that those others, the children of the desaparecidos, actually experienced.

Of course, even though the aggressive advertising of the Grandmothers was a determining factor that encouraged those who did not know their origins to begin the search, the simultaneous appearance of DNA testing was a powerful additional stimulant. DNA, as a new tool that offered the possibility of certifying the biological link by means of scientific tests, contributed to an increase in the number of subjects launching searches.

In the words of Eva Giberti and Carmen Gravino, echoes resound of the stories of Mariela, Cristina, Julieta, and Aída, who are merely examples of hundreds of similar stories of those who began to question their biological identities and set out on a search for the truth. For many, as we have seen, the specter of what happened during the military dictatorship has certainly served as a stimulus to follow that road. 


\section{Intuition}

The Case: Martin senses intuitively that he is the son of desaparecidos and shows up spontaneously at CONADI-the National Commission on the Right to Identity-to corroborate his suspicions.

The Characters

Martín García de la Paz / Martín Amarilla Molfino (the son)

Aída García de la Paz (the adoptive mother)

Jorge García de la Paz (the appropriator)

Guillermo Amarilla (the biological father)

Marcela Molfino (the biological mother)

Viviana Bernath: Have you always been called Martín?

Martín Amarilla Molfino: Yes, I'm Martín; my name has always been Martín. For many years I was Martín García de la Paz. Since I learned about my history, I'm Martín Amarilla Molfino. Besides, no one has ever been able to tell me what my biological parents had planned to call me, so I decided to continue to be Martin, because if there is one thing that I am and always have been, it's Martin.

V. B.: When were you born?

M. A. M.: I was born on June 27, 1980, in Campo de Mayo. ${ }^{6}$ I always knew that I was born in Campo de Mayo, by Cesarean. In fact, my first birth certificate, the false one, shows my true date of birth and the true place where my mother had me: Campo de Mayo. Obviously, instead of my parents' names it has Aída and Jorge, my appropriators. It made perfect sense to me that I was born in Campo de Mayo, because Jorge worked in Army Intelligence and the base hospital was the right place for his wife to go for medical services. Aida was a pharmacist. They raised me as if I were their son. They never told me that I was adopted. Obviously, they weren't going to tell me that they had appropriated me. I was an only child. I knew that several years before they had me-received me-Aida had lost a baby. At home they often talked about that baby girl who died the same day she was born.

I grew up in Ramos Mejía and I still live there today.

The truth is, I had a happy childhood. I was never abused, and I received good care, with affection. It was actually Aida who took care of me. Jorge was a man with many personal problems. He was an alcoholic, and I never spent much time with him. Except when he was sober. He always treated me correctly, but the

6. Campo de Mayo is a military base northwest of Buenos Aires. During the military dictatorship, it was the site of several detention centers for the desaparecidos. Trans. 
truth is that we never had a close relationship. He died when I was fourteen. It has always seemed odd to me that I wasn't sad when he died. He didn't have much of a place in my life.

Today, when I look back at my childhood memories, I begin to understand that some of the fantasies that used to go through my head had a basis in fact. Even when I was little-five or six-I always had the sensation that Aida and Jorge were not my parents. I didn't have the nerve to ask them, but I suspected it. I made up stories. For example, they were too old to have a child my age. When I was born Aida was fifty years old, and he was somewhere around the same. Since they were very old to be my parents, I used to imagine that they were really my grandparents, that my parents had died and my grandparents had taken over to raise me, and that they didn't want to tell me about it because they didn't want me to be sad.

Another one: Since I clearly couldn't see that I resembled either one of them, I imagined that I must look like my grandparents, whom I had never met because I had such old parents. That's one question that I did ask. More than once I asked them who I looked like, and they always dodged the question. I remember perfectly when I hit puberty and my voice began to change, like those of my friends ... and while my friends' uncles and other adults used to tell them, "Your voice sounds just like your old man's," no one ever compared my voice to Jorge's. I could tell that my voice didn't sound like his. And today I realize that no one ever said anything to me about any resemblance because those who were close to my parents knew that I wasn't really their son.

Different arguments were always coming up to make me wonder about my origins, but I would always find an answer quickly, trying to convince myself that those doubts were just nonsense.

But it's interesting that where I felt our differences the most was not in physical appearance, but in our worldviews. My way of looking at the world was totally different from Jorge's and from what he had taught me.

V. B.: For example?

M. A. M.: One time, when I was ten, I asked him a question about Che Guevara. He went crazy and told me, "He's a son of a bitch." I didn't believe what he told me and I started investigating who he was. I asked my friends' parents, but I wasn't satisfied with their answers. On another occasion I drew a V on a piece of paper, symbolizing Viva Perón and the Peronist Youth movement. "What is this?" I asked him. He wanted to kill me when I went to him with questions like that. They made him uncomfortable.

It must have hurt Jorge a lot to watch me grow up and realize that I looked more and more like his rival rather than what he wanted his son to be. I'm convinced that he knew very well who my dad was. Because Guillermo, my old man, 
was a guy that everyone in the Intelligence services was looking for . . he was a prize to be coveted.

But, anyway, except for those differences and the fact that they always lied to me about my origins, everything else was pretty good.

The change came in 1996. I was finishing high school and I had a Literature teacher who used to talk to us a lot about the '70s. He even showed us the film The Night of the Pencils, about the students who were abducted and tortured and then disappeared . . . He told us about the dictatorship and the desaparecidos ... He explained how the repression worked systematically. He opened a lot of eyes and minds. As for me, well, he split my brain in two! Besides, all of this was risky for him. It was a religious school, and he talked to us secretly. Something clicked with me, and from that time on, I first began to wonder if I might actually be one of the children of the desaparecidos.

V. B.: And it made sense to you?

M. A. M.: Yes, the more I thought about it, the more convinced I became. Everything fit perfectly. Jorge worked for the Army, in the Intelligence Service; he worked there until the day he died. But I didn't have the courage to ask anyone anything. I didn't dare even hint at my suspicion that I wasn't their biological son. Not even years later, when I felt like I was drowning in uncertainty. I was afraid to ask Aida. It hurt me to think that my questions might cause her suffering. Besides, at that time it had been only a few years since Jorge's death, so I decided to let it go and get on with my life, as if nothing was wrong.

I finished high school and began to study guitar at the Conservatory of Music. I had always loved music and had been taking guitar lessons since I was thirteen. But after two years I left the Conservatory and began to study Literature at the University of Buenos Aires. Again, I stayed for two years. Nothing really satisfied me. It was as if I was looking for something and I didn't know what. My studies were part of the search.

V. B: And what did Aida have to say?

M. A. M.: The good thing through all that, strange but good, was that Aida supported me whatever I did. If I decided to study Art, she agreed with my decision, if it was Literature or the Conservatory, the same... I was always free to choose. I finally finished a degree in Theater. I worked as an actor for a while.

I began to wake up around 2003 or 2004, when the Grandmothers became more aggressive in their ad campaigns and movies were coming out about the dictatorship. On TV or on the street, they were sending a clear message: If you're wondering about your identity, talk to the Grandmothers; you might be a child of desaparecidos. I heard that scads of young people showed up. I let a few more years go by.

V. B.: When did you make the decision? 
M. A. M.: I'll never forget it. It was an evening in 2007. I was with my girlfriend, watching Televisión por la Identidad, ${ }^{7}$ the chapter about Juanca . . . And when the program was over I burst into tears. Then I told my girlfriend everything, my whole story. She wasn't surprised. She had also suspected that I might be a child of desaparecidos, but she didn't know how to bring up the subject for fear of hurting me. Back then I had some strange attitudes. For example, I would go to my drama classes wearing a T-shirt with a GrandMothers of Plaza de Mayo design. When my girlfriend saw me wearing that shirt she would make comments, telling me that it was weird for a man of my age, who didn't have anything to do with the history of the desparecidos, to be wearing that shirt. Not long after that, she told a friend about my suspicions, and I realized that nobody was treating me like I was crazy. On the contrary, they supported me. I couldn't stand it anymore. My head was exploding. I was twenty-seven years old. Then one day my girlfriend said, "Let's go to CONADI" I went. We went together.

It was October of 2007. I introduced myself and told them my story. I told them that I thought I was the son of desaparecidos. I had taken photos with me, and a photocopy of my birth certificate. I tried to explain why I had so many doubts, because I really didn't have any material proof, just feelings. I gave them the information that seemed important to me. I had told them only a couple of things when I realized that they believed me, that my history was just like theirs. They took me seriously. The data was very convincing. I had been born in Campo de Mayo, in 1980. Jorge was in the military, an auxiliary accountant attached to the $601^{\text {st }}$ Battalion. That battalion was the bloodiest among the Intelligence Services, the one responsible for many kidnappings, including those of my parents. It was the battalion that supported the coup in Bolivia. It was a very powerful organization. Besides, the birth certificate was signed by a doctor named Caserotto, who had been accused of stealing babies. Another striking fact was their age at the time of my birth. A few days later they gave me the medical order to have a blood sample taken at the Durand Hospital, at the Genetic Data Bank. They would test my sample against those of all the families of desaparecidos who were looking for a missing boy. While I waited for the results I tried to go on with my life and not think too much about it.

V. B.: And when the results came in?

M. A. M.: It was terrible, in March of 2008, five months later. They called me in and told me that they didn't find a match and that I wasn't the son of desaparecidos. After I got the results I told myself, "Well, that's that. On to something else." And I dropped the subject.

But then something incredible happened. A year and a half later, on a Friday, I got a call from CONADI. They asked me if I could come in on the following

7. Miniseries dramatizing actual cases of children of desaparecidos. The second of three episodes is about Juan Cabandié ("Juanca"). The series won an Emmy in 2008, among other awards. Trans. 
Monday-I'll never forget it. It was November 2 of 2009. I didn't know why they had called me, but since I was going, I had decided to take them some photos of Jorge with his friends. I think that, in my heart, I had not accepted that "you are not the son of desaparecidos" and I was planning to insist that they reopen my case and analyze it again.

When I arrived at CONADI that Monday, the president of the organization, Claudia, met with me. We chatted for a while. She seemed nervous. At one point I showed her the photos that I had brought with me. She glanced at them but did not seem very interested. I didn't understand what was going on. Also, I noticed that the guys who worked there kept spying through the office window. There seemed to be a lot of movement around there. Suddenly, Claudia started to talk. She told me the whole history of a family. It was an impressive history. When she had finished, she blurted out, "And that is your family." Then she showed me the DNA tests and the results. There was a probability of better than $99.99 \%$ that I was the son of Guillermo Amarilla and Marcela Molfino. There was no room for doubt; the results of the DNA analysis were unassailable. That was my family. That was my history.

I hadn't even had time to react when Claudia told me that my entire family was gathered at the headquarters of the Grandmothers because they wanted to meet me. Carefully, she asked me if I would agree to that. I didn't hesitate, not for an instant. I immediately said yes. We went out to the street and took a taxi. I didn't understand a thing... I went into a state of shock that day, and for the next week I walked around like I was living inside a movie... .

When we got to Grandmothers, Estela [Carlotto, the president of the Grandmothers of Plaza de Mayo Association] was standing at the door waiting for me. She hugged me. I took a few more steps and saw something like sixty people waiting for me. They looked like a crowd of fans at a soccer match. Everyone started to greet me, and I greeted them back. But what thrilled me the most was that I had three brothers-Mauricio, Joaquin, and Ignacio. All three of them were there. They are five, three, and one year older than me. I'm thirty now, and they are thirty-one, thirty-three, and thirty-five, close together... When my parents disappeared, she was twenty-seven and he was twenty-nine. The boys were four, two, and ten months old. It was really amazing...

There were a lot of people at Grandmothers. I was so excited that I didn't know what to do with myself. I went from one person to another; I hardly remember anything that they said to me. Fortunately, there are videos that people took that day. I watch them sometimes... I like to watch them. Some people cried, others stared at me as though they were hypnotized, and others laughed. There were friends, cousins, aunts and uncles, and a grandmother. I had gone there alone. After a while my girlfriend arrived. We must have stayed there at Grandmothers for about two hours that day. Then all of us went out to eat together. There were a lot of us. 
My parents are were?Marcela Molfino and Guillermo Amarilla, two young people from Chaco. They were educated and they were activists; they served in the Montoneros. My father was one of the founders of the JP, the Peronist Youth, in the Northwest Region. Later he was a Montoneros leader in what would be the AL IV Region that included Chaco, Formosa, and Corrientes. My mother belonged to Peronismo de Base. When she met my father she switched to the JP and from then on they were together. My father needed just three more classes in order to graduate as an accountant, and my mother was studying philosophy. When they were taken they had three young sons. My oldest brother was born in Chaco. The second was born in Buenos Aires and the third in France, because my parents were in exile in late 1978. First they were in Mexico, then Spain, and finally in France. They were part of a guerilla group that was training overseas in order to return to Argentina with the fantasy of finally declaring a revolution. At one time they had the option of leaving my brothers in Cuba, because there was a pact between Montoneros and Cuba in which they agreed to protect family members. But they didn't want to leave them; they wanted their sons with them. They always took their sons with them. In 1979 they were ordered back to Buenos Aires. They settled in the western zone.

Soon afterwards, both of them were kidnapped. My dad was taken in Ramos Mejía, my mom in San Antonio de Padua. When they came into the house and kidnapped my mom, my three brothers were there, along with my uncle and aunt and their son. They took my mom with her three boys and my uncle with his son. My aunt managed to escape. My oldest brother, who was four years old at the time, remembers that day perfectly. He says that he was playing in the doorway of the house and then he looked up and saw a truck, and in the back of the truck was a pile of boots... He says that he will never forget that image "of a pile of boots." Another thing that stands out in his mind is the way they dragged my mom out of there by her hair. They kept the four boys-my three brothers and my cousinkidnapped for fifteen days, and then luckily they delivered them to Chaco, leaving them at an aunt's house. My three brothers were raised in the home of a paternal uncle. After a while, my cousin went to Sweden, because his mother had managed to escape. My mom and dad were held in the ESMA detention center. No one knew that she was pregnant when she was taken. Perhaps even she did not know it, or she may have become pregnant in captivity. No one looked for me, simply because no one had ever reported that my mother was pregnant when she was taken. That was why the Durand Hospital had no blood samples from my relatives to match with mine.

What was really strange is that in 2009 two reports came in, by completely different routes, stating that Marcela Molfino had been seen to be pregnant and that she had given birth. One of the reports came from a repentant military man and the other from a woman who was also being held in Campo de Mayo and who insisted that she had seen Molfino pregnant. Putting all the information to- 
gether, they decided that I was probably Marcela's son. It seems that my case had made an impression in CONADI and they immediately associated me with the son of Marcela Molfino. Then they called in my uncles, brothers of both of my parents, to Durand Hospital to take blood samples and compare my DNA with theirs. The results were as I told you before, that I was a son of desaparecidos.

It's odd that the woman waited until 2009 to report my mother's pregnancy. If I had reported my case ten years earlier, I still would not have known the truth until November 2 of 2009. It's crazy, because my brothers were also returned to the family on November 2.

Although we suppose that when Marcela was kidnapped even she probably did not know that she was pregnant, there is now another theory, which is that my parents may have had relations while they were captives, in ESMA. My date of birth is well within the limits of both possibilities. There is also testimony of a woman who was held in Campo de Mayo, which was essential to bringing my case to light, in which she says that one of the men who were keeping her prisoner, and who liked to talk, had told her, "Well, we're not going to let couples stay together now, because we don't want any repeats of what happened in ESMA with Amarilla and Molfino." It may have been just a rumor.

They say that my mother was transferred to Campo de Mayo for my birth, and that afterwards, well ... they got rid of all the women once they had given birth. There are rumors about my father, saying that they held him captive until 1982. That when he died he was bedridden on a stretcher, that they had tortured him terribly. He finally died, but his body was never found. Neither his nor hers.

$V$. B.: You are one of the youngest of the children...

M. A. M.: In fact, I'm the last child of desaparecidos to be born in captivity, the youngest of the children of desaparecidos. Because my parents were kidnapped on October 17, 1979. Yes, although many people don't know it, they were still kidnapping people in '79. Even afterwards. My parents belonged to the round of kidnappings of people who had returned to the country from exile to take part in the counteroffensive. Until a short time ago, it was believed that there were no cases of children of desaparecidos who were born in '80. But when people started to talk, and some of the midwives who worked in the Campo de Mayo gave their testimony, confessions came to light, including one that included my case. Many years later, a midwife said, "I helped a slim woman give birth..." and she described a woman who sounded like my mother.

V. B.: What about Aida? Did you tell her that you were searching for your identity?

M. A. M.: Not at all. I carried out all of my search behind Aida's back. To me, she was my mom, and I didn't want to hurt her. Besides, many times I thought that maybe I was mistaken and that she really was my mother. If that were true, telling her about my doubts about my identity would have hurt her very much. I was confused. I had a lot of guilt and fear of being wrong. I had never even had 
the courage to ask her if I was her son, either when I was little and suspected that I was adopted or later when I started gnawing at the idea of being a child of desaparecidos. I never reproached her; she has enough guilt already. I know that she made a mistake; I know that it's not right that she didn't tell me the truth . . but I love her and I try to understand her.

However, just as soon as I knew my actual history, I decided to talk to her. I found out on a Monday, and I went to see her on Thursday of the same week. I was now living alone. I remember that I was with my girlfriend in my room and I went round and round, trying to get up the nerve to confront her, repeating over and over, "I have to tell her, I have to tell her," but I couldn't do it. Finally my girlfriend just yelled at me, "Go on and tell her already!" She pushed me out and closed the door. She was right. I told Aida everything. It was a good conversation.

For the first time, she was honest with me. She told me that when they received me, I was not even a day old. At first, she didn't know where they were bringing me from. Jorge had told her that in Campo de Mayo there was a woman with a cerebral aneurysm, that she wasn't going to live long and that she was about to give birth. That the baby was going to be left alone. That if the baby were given in adoption it would be in a home for a while, and that would not be good for the child. Jorge told her that he had a friend at the hospital who could sign as if the baby were theirs and take it directly to them. Aida confessed that she wanted so badly to have a child that she didn't ask questions and accepted Jorge's story. It was a week after they received me that she asked Jorge about my mother and told him that she would like to meet her, because she wanted to know what I was going to be like when I grew up. He replied that she had died after giving birth. And they never talked about it again. Aida told me that day that only recently, years later, when the Grandmothers started talking through different media about the desaparecidos and their children, she began to suspect where I had come from. Obviously, she knew that they had not adopted me legally, but she said that in those days it was common to obtain babies and register them as one's own. Maybe that's the truth...

She also told me that she had never confessed that I was adopted (because she wasn't going to say "appropriated") because she was so afraid that I would be angry, not only with her but also with life, that I would go away, that I would fall off a cliff.

V. B.: And how are you getting along with your new family?

M. A. M.: My biological family is very large. There are about two hundred on my father's side and sixty on my mother's. My dad had ten siblings, and they all had children. Both families are very involved in politics. On my mother's side there were six siblings, and five of them were activists. She was the only one who disappeared. One uncle was a prisoner for six years and then they freed him, and two went into exile. 
I'm still in contact with my relatives who live in Buenos Aires, and also with the ones in Chaco.

The greatest thing was finding three brothers. It was great for me, who had never had any, and for them, since they used to be three but now we're four. I didn't even know what it was like to have a brother. I'm learning to be a brother. I know I'm not going to shoot marbles with them, but we are going to establish a bond ... and maybe we will shoot marbles too.

To me, the one who looks the most like me is the youngest. When my friends met him, they were astonished at the resemblance. But I feel a very special affinity with him because of his sense of humor. He has a very sharp sense of humor, which is typical of my mother's family. Yes, they have a great, a very great sense of humor. A sense of humor that I recognize in myself ... I often relate to people through humor. My oldest brother and I share a calm, peaceful way of being, which both of us have and transmit. I'm just now getting to know them, but I identify with each of them in one way or another. Ways of moving, of sitting, gestures...

Also, those who knew my dad say that they recognize some of his gestures in me. For example, I really like to sit crossing my legs Indian-style. And my old man used to sit the same way. Or when I sit at a table, I always rest one hand-both if I can-on the table as comfortably as I can, and they tell me that he sat that way too. There are even photos of him where he's sitting the same way I sit. Others say that I walk like him, or that I hold the guitar the same way he did. That I talk like him; that I have the same timbre in my voice. I'm very calm; I seldom get angry or shout. And they tell me that he was the same. He raised his voice only when he was arguing about politics. With his friends, he was very peaceful. Even as a leader, when he had to use a microphone and speak in public, he always spoke peacefully. I happened to meet some of his old companions, from his days as an activist, who started to cry as soon as they saw me and heard me speak a few words. When they met me I was the same age as my father when they kidnapped him, twenty-nine.

It's strange to think that even though I've known my biological family for only a short time, I feel that I identify with them completely. I was moved when I learned that I have relatives who are musicians or who love music on both my father's and my mother's side. My greatest surprise was finding out that when my mom was a girl, she played the accordion, because I play the accordion, and that is not a common instrument to choose. My maternal grandfather was a jazz pianist, a poet and a writer... He loved music, and his children took after him. My maternal aunt was a concert pianist ... On my father's side they're more chamameceros-my dad played the guitar and sang.

Apparently I also share with both of them a taste for reading. My dad was a great reader. They say that my mom was amazing at writing book summaries. 
Sometimes in her studies she had to summarize a book and write an abstract and she would do it in one night; she was awesome! Me, I love to read.

As for their militancy, even though I was never an activist, I identify with the left. Since December of 2009 I have been working three days a week, for a salary, at the Dirección Nacional de Juventud, in the Ministry of Social Development. There, we are activists through our work. Our work is to go to the barrios and slums, approach the people, and make proposals for a variety of activities. I work in the area of Culture. My responsibility and objective is to promote cultural activity in the barrios. We try to set up musical groups; in some neighborhoods there are already orchestras. I also am a guitar teacher; I give private lessons and also teach at an institute.

I'm very proud of my parents. I have a recording that they made two months before they were kidnapped. My mom speaks for about twenty minutes, and my dad for half an hour. Both of them speak to their children and explain to them that the struggle they are carrying out has much to do with the world that they want for their children. It's very beautiful to hear.

It never crossed my mind to reproach them for their decision to fight.

But I also want to salvage much of what I received from Aida, who is my mom, after all. What I value the most is the freedom with which she raised me. The freedom to make my own decisions about my life. When I talk to others who were appropriated, their heads are going around in circles because they were raised by people who tried to inculcate in them, when they were very young, a way of viewing the world-a way of thinking - that was very different from that of their biological families. When they learned about their true histories, many of them felt rejected by their adoptive families. I was always allowed to think freely. I had the freedom to study what I wanted, to read what I wanted, to work for a political party or go into the slums... Aida gave me freedom; I didn't see much of Jorge, and besides, he died when I was young.

When I stop to think who I am, what I am like, and why I am the way I am, I realize that those answers are in my history. My identity is the product of that history. I am convinced that while I was in my mother's womb, I must have formed an intimate relationship with her. It is the only place in which I ever knew her.

For a long time I didn't have a clear sense of who I was. I was searching but didn't understand what I sought. Now that I know my true identity, things are beginning to fall into place. Before, it felt like someone was holding a book and reading random pages, out of order. There was no coherence to my life. Now I know that when I finish a page, I can read the next and understand a little better who I am, and I can progress as I read more pages.

There are things that it is hard for me to put into context. I don't understand where they came from and I can't imagine where they are going. I believe that this is a real sensation of the lack of identity. There is no structure for growth, for building a framework. It's crazy. I used to have an image that would pop into 
my head, of a library where one shelf would be full of books that were standing up straight while in another, all of the books were crooked and twisted. It was a very disorganized, unstructured library. All of the books were out of place. Now I understand the significance of that image. I can start to put the books where they belong, each in its own place-books of art, of poetry, novels...

V. B.: You felt that something was out of place...

M. A. M.: Clearly I was living with the perception that I was not where I was supposed to be. I knew that all my life. I felt that the house that was my house was not my place. I was convinced that some other place was waiting for me. I don't know how or why I felt what I felt, but those sensations went all through my body.

But there are two stories that I keep coming back to, that show me that in some corner I knew very well who I was. I always liked to ride a bicycle. One of my favorite routes was the one from Ramos Mejía to San Antonio de Padua, some thirty-five minutes on the train. When I reached Padua, I would ride around for a while on my bike, then walk for a while. I loved to walk there. I always used to say that Padua was very pretty and that I would like to live there. (In fact, I would still like to move to Padua.) At first, when I would talk about it, my friends would ask, "Why Padua?" I would tell them it was because I found it enchanting. When I learned my history, I found out that my parents had lived in Padua when they returned to Argentina. It was as if I had some sort of registry of my family's past, as if it had somehow been transmitted to me.

The other story has to do with an image that came to me repeatedly. Once I was conversing with a cousin in Córdoba. She asked me whether I had any memories related to torture, something from back when my mother was pregnant with me. Then I remembered an image that would come to me every time I walked to a certain friend's house. She lived in a barrio where there was a lot of green-many houses with gardens at the front door. When I would leave her house and it was nighttime, I would walk along there, and I would think that if anyone were following me there in the night, I could make a hole in the ground there in the garden, get into the hole, and cover myself up. Yes, I imagined myself at night making a hole in a little garden. And they tell me that my dad used to do things like that. He would make holes in the ground where he could crawl in, cover himself up, and be safe. It's incredible, but what they told me that he did a couple of times is the same thing that I imagined myself doing as I walked and fantasized. The question is, why did I imagine that I was being followed? What was I afraid of? From whom was I hiding? Then she told me the story of my father hiding, on the hillside in Tucumán... because he would hide on the hillside.

I feel that the worldview that I had came from somewhere. I wonder, is it in the genes?

How difficult to answer. In the case of the children of desaparecidos, there is probably an unconscious perception of the period of gestation and, surely, tho- 
se who raised them also must have transmitted something ... probably not what they wanted to transmit. It is very strange, but that perception must have existed within Martín, for example.

Rather than genetics, Martín may have perceived Jorge's efforts to distance him from his origins. In Martín, perhaps it backfired. Even though they did all they could to keep him from learning the truth, he went on his own to search for it. His reactions spoke much louder than his words...

On the other hand, we should point out-and remember-that, at present, the study of genetics still knows very little about what it determines, and what it does not, in the construction of identity. 